\title{
Okulöncesi Eğitim Kurumu Müdürlerinin Yönetim Becerileri ile Etkileme Güçleri Arasındaki İlişkilerin Öğretmen Görüşlerine Göre İncelenmesi
}

\author{
Cebrail HAVEYDI', Yusuf ALPAYDIN**
}

Öz

Bu çalışmanın amacı okulöncesi eğitim kurumu müdürlerinin yönetim becerileri ile etkileme güçleri arasındaki ilişkilerin öğretmen görüşlerine dayalı olarak tespit edilmesidir. Araştırmanın evrenini, 2015-2016 eğitim-öğretim yılında İstanbul ili Pendik ve Tuzla ilçesi sınırları içerisinde yer alan resmi ve özel okulöncesi eğitim kurumlarında (Bağımsız Anaokulları) görev yapan öğretmenler oluşturmaktadır. Örneklem ise bu genel evren içinden basit tesadüfi örneklem alma yoluyla belirlenen 155 öğretmenden oluşmaktadır. Araştırmada veri toplamak amacıyla Şekerci (2006) tarafından geliştirilen "Okul Müdürlerinin Öğretmenleri Etkileme Ölçeği” ile Quast ve Hazucha (1992) tarafından geliștirilen "Yönetim Becerileri Ölçeği kullanılmıştır. Araștırmada öğretmenlerin okul müdürlerinin yönetim becerilerine ilişkin görüşleri cinsiyet, medeni durum, yaș, kıdem, öğrenim durumu değișkenlerine göre toplam ölçek ve hiçbir alt boyutta farklılaşmamaktadır. Öğretmen görüşlerine göre okul müdürlerinin yönetim becerileri öğretmenlerin okuldaki çalışma süresi, okul türü değişkenlerine göre farklılaşırken, cinsiyet, yaş, okuldaki çalışma süresi değişkenlerine göre farklılaşmamaktadır. Okul müdürünün öğretmeni etkileme düzeyi öğretmenlerin medeni durum, kıdem, öğrenim durumu, okul türlerine göre anlamlı ölçüde farklılaşmaktadır. Korelasyon analizi sonucunda yönetim becerileri ölçeği toplam puanları ve alt boyut puanları ile etkileme ölçeğinin yetki gücü alt boyutu arasında negatif yönde ilişki olduğu görülmüştür. Yönetim becerileri ölçeği puanları ile etkileme ölçeğinin alt boyutları olan uzmanlık gücü ve kişilik boyutları ile pozitif yönde anlamlı ilişki bulunmuştur. Buna göre yetki yönetim becerileri arttıkça yetki gücünün kullanımı azalmakta uzmanlık ve kişilik güçlerinin kullanımı da artmaktadır.

Anahtar Kelimeler: Yönetim, Okul Yönetimi, Yönetim Becerileri, Etkileme, Etkileme Güçleri

\author{
Özgün Araştırma Makalesi (Original Research Article) \\ Geliş/Received: 08.05.2017 \\ Kabul/Accepted: 17.10 .2018 \\ DOI: http://dx.doi.org/10.17336/igusbd.310971 \\ *Öğretmen, Milli Eğitim Bakanlığı, İstanbul, Türkiye, E-posta: cebrailhaveydi@hotmail.com, \\ ORCID ID https://orcid.org/0000-0002-6578-9722 \\ Dr. Öğr. Üyesi, Marmara Üniversitesi, Atatürk Eğitim Fakültesi, İstanbul, Türkiye, \\ E-posta: yusuf.alpaydin@marmara.edu.tr, ORCID ID https://orcid.org/0000-0001-8263-8793
}




\title{
The Investigation of the Relationship Between the Management Skills and Influencing Powers of the Preschool Education Directors According to Teachers' Opinions
}

\begin{abstract}
The main purpose of this study is to examine the relationships between the management skills and influencing powers of the preschool education institution managers according to the preschool teachers' opinions. The population of the study consists of the teachers working in the public and private preschool education institutions (Independent Kindergartens), which are located within the boundaries of Pendik and Tuzla district of Istanbul, in the 2015-2016 academic year. The sample consists of 155 teachers, who were identified by simple random sampling from this general universe. In order to collect data, Principals' Influence Scale on Teachers developed by Şekerci (2006) and Management Skills Scale developed by Quast and Hazucha (1992) were used. According to research findings, teachers' views on the management skills of school principals do not differ according to gender, marital status, age, seniority, and educational status in the total scale and no sub-dimension. The management skills of school principals vary according to teachers' working time and type of school, but they do not differ according to gender, age and working time variables. The school principal's tactics to affect teachers differ significantly according to teachers' marital status, seniority, educational status and school types. As a result of the correlation analysis, it was observed that there was a negative relationship between the management skills scale total scores and sub-dimension scores, and the authority power sub-dimension of the influence scale. Significant positive relationship was found between the management skills scale scores and expertise and personality dimensions of the influence scale. Accordingly, as management skills increase the use of power of authority decreases and the use of expertise and personal powers increases.
\end{abstract}

Keywords: Management, The School Administration, Management Skills, Influencing, Influence Powers

\section{Giriş}

Günümüzde genel olarak 0-8 yaş aralığındaki erken çocukluk yıllarında çocukların eğitimine büyük önem verilmektedir (Gültekin, 2008; Ceyhan, 2011). Çocukları okulöncesi dönemde okumaya özendirmek, onlarda kitap ve okuma sevgisi oluşturacak öyküleri ve öykücüleri açığa çıkarmak, geleceği oluşturacak çocuklarımızın okuma beğenilerini geliştirmek, yeni ve yaratıcı düşünceleri açığa çıkarabilmek, sözcük dağarcıklarını geliştirmelerine firsat ve olanak yaratmak, ifade güçlerini geliştirmek, hayal dünyalarını keşfetmek, duygularını tanımalarını sağlamak ve problem çözme becerilerini görmek için okulöncesi eğitim gereklidir.

Tüm kademelerde olduğu gibi okulöncesi eğitimde de eğitimin verimliliği okul yönetiminin amaçlarını gerçekleştirmesine bağlıdır. Okul yönetiminin amaçlarını 
gerçekleştirmesi ise büyük ölçüde okul yöneticisinin, yönetim ve liderlik yeterliklerine sahip olması ve bunları uygulayıp çalıșanları etkileyebilmesine bağlıdır. Yönetim becerileri en genel anlamda kurumlardaki yönetim süreçlerini etkili bir şekilde yönetmeyi kapsamaktadır (Bursalıoğlu, 2012).

Okul yöneticileri bulundukları pozisyon gereği görev yaptıkları kurumun lideri konumundadırlar. Bu yönüyle kişileri ve grupları yönetir ve yönlendirirler (Açıkalın ve Şişman, 2007). Okul müdürü bu açıdan belli yeterliliklere sahip olmak durumundadır (Şişman, 2017). Okul yöneticisi eğitim yöneticisi olarak değişimden en çok etkilenmesi gereken kişilerdendir. Düşünce ve davranışını çağın gerektirdiği eğitimsel bakış açısıyla dizayn etmek zorundadır (Çelik, 2003). Bilgi paylaşmak, ihtiyaçlarını gidermek, yardımda bulunmak, arkadaşça sohbet etmek gibi nedenlerle kişi iletişim kurar (Yüksel, 2012). Okuldaki iletişim kanallarının açık olması, okul personelinin okuldaki tüm etkinlikler hakkında bilgi sahibi olmalarını sağlar (Aydın, 2005). Okul müdürlerinin, etkileme davranışları yönetim yeterliliğinde önemli bir göstergesidir (Akçay, 2003).

Farklı tasnifler olmakla birlikte yönetim süreçleri denildiğinde karar verme, planlama, örgütleme, iletişim, etkileme, eşgüdümleme ve değerlendirme kavramları öne çıkmaktadır. Yönetim süreçleri içinde birinci sırada karar verme gelmektedir. Herhangi bir karar verilirken yaşanılan aksaklıklar ve çatışmalar bu sürecin doğru kullanılması ve doğru yönetilmesi ile çözüme kavuşturulabilir. Bu nedenlerden dolayı karar verme sürecinin önemi çok büyüktür (Gürsel, 2007). Planlama, bir yönetim süreci olarak "örgütsel amaçlara yoğunlaşmayı, örgütsel amaçlara ulaşmayı sağlayacak alternatif yolların ve araçların belirlenmesini ifade etmektedir" (Balcı ve Aydın, 2001). Örgütleme ise kaynakların ve çalışanların planlar doğrultusunda yönlendirilmesi ve organize edilmesini kapsamaktadır.

Günümüzde yönetim süreçlerinde iletişime verilen önem giderek artmaktadır. İletişim süreci örgütlerde informal ve formal olmak üzere iki gruba ayrılmaktadır. Örgütün hiyerarşik kademeleri arasında emirlerin en alt kademeden en üst kademeye kadar çift yönlü aktarılması formal iletişimdir. Örgütteki kişiler arasındaki sosyal etkileşimlerin iletilme süreci de informal olarak tanımlanmaktadır (Taymaz, 2003). Örgütlerde yönetim süreçlerinden biri de etkilemedir. Örgütteki bireyleri etkilemek ve onları istenilen yöne doğru yöneltebilmek genellikle teşvik ve özendirme kullanılır. Özendirme iki temel yapı taşı üzerine oturtulmuştur, bunlar maddi ve manevi boyutta yapılandırmadır. Etkilemede ki önemli tekniklerden biride örgütte çalışanların yönetimsel kararlara katılımları sağlanmalarıdır. Bu durumlarda örgütte çalışanların örgütün hedefleri doğrultusunda çalışmaları ve odaklanmaları artmaktadır (Gürsel, 2007).

Örgütün hedeflerinin gerçekleşmesi açısından bir diğer önemli süreç eşgüdümlemedir. Örgütün ortak hedeflerine ulaşllabilmesi için görevlerin doğru dağıtılması, çalışanların iyi ilişkiler kurması, zamanların doğru ayarlanması gibi etkenler önemlidir. Bir örgütte hiçbir nedenle çalışan kendi istekleri doğrultusunda hareket edemez. Ortaya konan sonuçların iyi değerlendirilmesi ve çalışanların birbirinden haberdar olmaları çok önemlidir (Balcı, 2005).

Yönetim süreçlerinin sonuncusu denetleme ve değerlendirmedir. Bir örgütün amacına ulaşıp ulaşmadığını değerlendirmek kritik süreçlerden biridir. Değerlendirme 
sürecinin başarısı eldeki verilerin doğruluğu ve güvenilirliği ile önemli ölçüde ilgilidir. Yöneticilerin veri toplama, ölçme ve değerlendirme alanında yetkin olması önem taşımaktadır (Başaran, 2006).

Kurumların başarısı yöneticilerin çalışanları etkileyerek yönlendirebilmesine bağlıdır. Bu amaçla yöneticiler çeşitli güçleri kullanırlar. Güç birisine kendi istediklerini yaptırabilmektir. Yöneticiler güçlerini çeşitli kaynaklardan sağlar. Yöneticilerin çalışanları etkilemede kullandıkları güçler farklı çeşitlere ayrılır; zorlayıcı güç, uzmanlık gücü, meşru güç, yasal güç ve referans gücü. Zorlayıcı güç, ödüllendirme işleminin tam tersidir yani ödüllendirmeden daha çok cezalandırma, baskı kurma ve çalışanları korkutarak istediğini yaptırmadır. Örneğin, disiplin suçu verme, tehdit etme düşünülebilir. Meşru güç, yöneticinin çalışanlarının değer ve inançlarından aldığı güçtür. $\mathrm{Bu}$ güç var olduğunda çalışanlar yöneticinin kendilerini kabul etme hakkının bulunduğunu kabul ederler. Uzmanlık gücü, çalışanların, yöneticilerin kendilerinden daha deneyimli olduğuna ve yargılama gücüne sahip olduğunu kabul etmesidir. Referans gücü, çalışanların kendilerini yöneticilerle özdeşleștirdiği, yöneticileri güvenilir ve saygın görmesi yoluyla oluşan bir güçtür. Yasal güç ise kaynağını yazılı metinlerden, yasalardan alan güçtür. Yöneticinin bu gücü makam gücünden gelmektedir (Koçel, 2011).

Okul öncesi eğitim, gelişimsel kuramlar dikkate alındığında çağdaş eğitim anlayışı içindeki en önemli eğitim basamağıdır. Bu açıdan okulöncesi eğitimin yaygınlaştırılması sunulan hizmetlerin verimliliği ve etkinliği önemlidir. Okulöncesi eğitim kurumu yöneticisinin okulöncesinde çalışan öğretmenleri motive ederek etkiliyor olması onlar üzerindeki olumlu etkisini artıracak eğitimsel ve yönetimsel tedbirleri alıyor olması bu ölçüde verimliliğine katkı sağlayacaktır. Bu sebepten bu araştırmada okulöncesi eğitim kurumu müdürlerinin yönetim becerileri ile etkileme güçleri arasındaki ilişkilerin öğretmen görüşlerine göre incelenmesi hedeflenmiştir.

Tüm bu açıklamalar ışığında eğitim yöneticilerinin yönetim ve öğretmenlerini etkileme düzeylerinin belirlenmesi araştırmanın temel amacını oluştururken, öğretmenleri olumlu yönlendirmelerinde etkili olduğu düşünülen etkileme becerilerinin neler olduğunun ve bu becerileri etkileyen değișkenlerin neler olduğunun daha önce yeterince çalışılmamış olması bu araștırmayı gerekli kılmaktadır.

\section{Yöntem}

Bu araştırmada; okul öncesi eğitim kurumu yöneticilerinin yönetim becerileri ile öğretmenleri etkileme güçleri arasındaki ilişkilerin değerlendirilmesi amaçlanmıştır. Araştırma var olan durumu olduğu gibi betimlemeye çalıştığı için ilişkisel tarama modeline uygun olarak düzenlenmiștir. Tarama modelleri, zamanı önemsiz ve durumu değiştirmeden betimlemeyi hedefleyen bir araștırma yaklaşımıdır. Çalıșmalara tema olan kişi veya nesne, kendi şartları doğrultusunda olduğu gibi değiștirmeden tanımlamaya çalışılır. Onları etkileme uğraşı içine girilmez. Bilinmez istenenler vardır ve oradadır. Önemli olan ona uygun bir şekilde gözlemleyip belirleyebilmektir (Karasar, 2006). 


\section{Evren ve Örneklem}

Araştırmanın evrenini, 2015-2016 eğitim-öğretim ylında İstanbul ili Pendik ve Tuzla ilçesi sınırları içerisinde yer alan resmi ve özel okulöncesi eğitim kurumlarında (Bağımsız Anaokulları) görev yapan öğretmenler oluşturmaktadır Öğretmenlerin tam sayısı bilinmemekle birlikte bu iki ilçede MEB'e bağlı 105 anaokulu bulunmaktadır. Bu bilgiden hareketle iki ilçedeki bu okullarda toplamda 500-600 arasında öğretmen çalıştığı düşünülmektedir. Örneklem ise bu genel evren içinden kolay örneklem alma yoluyla belirlenen 155 öğretmenden oluşmaktadır. Örneklem, evrenin yaklaşık 1/4'ünü kapsamaktadır. Öğretmenlerin demografik yapısı aşağıdaki tabloda sunulmuştur.

Tablo: 1 Örneklemin Demografik Yapısına İlişkin Özellikler

\begin{tabular}{|c|c|c|c|}
\hline Demografik Özellikler & Gruplar & $f$ & $\%$ \\
\hline & Erkek & 3 & 1,9 \\
\hline \multirow[t]{3}{*}{ Cinsiyet } & Kadın & 152 & 98,1 \\
\hline & Toplam & 155 & 100,0 \\
\hline & Evli & 100 & 64,5 \\
\hline \multirow[t]{3}{*}{ Medeni Durum } & Bekar & 55 & 35,5 \\
\hline & Toplam & 155 & 100,0 \\
\hline & $20-25$ yaș & 37 & 23,9 \\
\hline \multirow[t]{3}{*}{ Yaş } & $26-30$ yaş & 83 & 53,5 \\
\hline & 31 yaș ve üzeri & 35 & 22,6 \\
\hline & Toplam & 155 & 100,0 \\
\hline \multirow[t]{3}{*}{ Kidem } & $1-5$ yil & 115 & 74,2 \\
\hline & 6 yıl ve üzeri & 40 & 25,8 \\
\hline & Toplam & 155 & 100,0 \\
\hline \multirow[t]{4}{*}{ Çalıştığı Okuldaki Görev Süresi } & $1 \mathrm{yll}$ & 34 & 21,9 \\
\hline & 2 yll & 82 & 52,9 \\
\hline & 3 yıl ve üzeri & 39 & 25,2 \\
\hline & Toplam & 155 & 100,0 \\
\hline \multirow[t]{3}{*}{ Öğrenim Durumu } & Önlisans & 66 & 42,6 \\
\hline & Lisans & 89 & 57,4 \\
\hline & Toplam & 155 & 100,0 \\
\hline \multirow[t]{3}{*}{ Okul Türü } & Devlet & 112 & 72,3 \\
\hline & Özel & 43 & 27,7 \\
\hline & Toplam & 155 & 100,0 \\
\hline
\end{tabular}


Tablo 1'de görüldüğü üzere, örneklem grubu kişilerinin 3'ü $(\% 1,9)$ erkek, 152'si $(\% 98,1)$ kadındır. Katılımcıların 26-30 yaşında, 35'i $(\% 22,6) 31$ yaş ve üzerindedir. $115^{\prime} \mathrm{i}$ $(\% 74,2) 1-5$ yll, 40’ı $(\% 25,8) 6$ yıl ve üzeri kıdeme sahiptir. Katılımclların 34'ü $(\% 21,9) 1$ yıl, 82'si (\%52,9) 2 yıl ve 39'u (\%25,2) 3 yıl ve üzeri okuldaki çalışma süreleridir. 66'sı $(\% 42,6)$ ön lisans, 89'u $(\% 57,4)$ lisans mezunudur. 112'si $(\% 72,3)$ devlet okulunda, 43'ü $(\% 27,7)$ özel okulda çalışmaktadır.

\section{Veri Toplama Araçları}

Araștırmada veri toplamak amacıyla "Okul Müdürlerinin Öğretmenleri Etkileme Ölçeği" (Uygun, 2006) ile "Yönetim Becerileri Ölçeği" (Şekerci, 2006) ve "Kişisel Bilgi Formu" kullanılmıştır.

Kişisel Bilgi Formu: Araştırmacı tarafından oluşturulmuş ve öğretmenlerin demografik (cinsiyet, medeni durum, yaş, kıdem, okuttukları sınıf, eğitim durumu vb.) özellikleri ile ilgili soruları içeren bir formdur.

Yönetim Becerileri Ölçeği: Quast ve Hazucha tarafından geliştirilen, Şekerci (2006) tarafından Türkçeye uyarlanan "Yönetim Becerileri Ölçeği” kullanılmıştır. Ölçek, yönetim becerilerini beş alt boyut ve 34 maddede gruplandırmıştır. Bu alt boyutlar: İnsiyatif alma $(1,2,3,4,5,6,7,8)$, sorumluluk alma $(9,10,11,12,13,14,15,16,17,18,19,20,21)$, teknik beceriler $(22,23,24,25,26)$, diğer beceriler $(27,28,29,30)$ ve nitelik beceriler $(31,32,33,34)$ şeklindedir. Ölçek maddeleri geniş zaman kipli ve olumlu önermeler seklinde hazırlanmıştır ve 5'li Likert tipinde derecelendirilmiştir. Ölçeği değerlendiren kişilerin verilen önermelerin her birinde belirtilen görüșe katılma dereceleri Hiç Katılmıyorum (1), Katılmıyorum (2), Fikrim Yok (3), Katılıyorum (4), Tamamen Katılıyorum (5) şeklinde derecelendirilmiștir. Yönetim Becerileri Ölçeğinin geçerlik ve güvenirlik çalışmaları Şekerci (2006) tarafından yapılmış, ölçeğin iç tutarlılık kat sayısı olan Cronbach Alpha değeri 0.95 olarak bulunmuştur. Ölçeğin alt boyutlarının iç tutarlılık katsayıları: İnisiyatif alma (0.87), sorumluluk alma (0.87), teknik yeterlikler (0.69), ve diğer beceriler (0.94) seklindedir. Teknik yeterlikler alt boyutunun değeri diğerlerine göre biraz düşük olmakla birlikte kabul edilebilir bir düzeydedir (0.69). Düzeltilmiş madde-toplam korelasyonları en düşük 0.52 ve en yüksek 0.88 arasında değişmektedir.

Okul Müdürlerinin Öğretmenleri Etkileme Ölçeği: Araştırmada Uygun (2006) tarafından geliştirilen "Okul Müdürlerinin Öğretmenleri Etkileme Ölçeği” kullanılmıştır. Ölçek 3 alt boyut ve 30 maddeden oluşmaktadır. Ölçeğin, ilk on maddesi yetki yoluyla etkileme, ikinci on maddesi uzmanlık gücüyle etkileme, üçüncü on maddesi ise kişilikle etkileme davranışlarını içermektedir. Ölçek 5'li Likert tipidir. Ölçekte yer alan etkileme davranışlarının müdürler tarafından hangi sıklıkla kullanıldığını belirleyebilmek için "Her Zaman" (5), "Çoğu Zaman” (4), “Ara Sıra” (3), “Çok Nadir” (2), "Hiçbir Zaman” (1), biçiminde sıralanan eşit aralıklı ölçek kullanılmıştır. Ölçeğin geçerlik güvenirlik 
çalışmaları Uygun (2006) tarafından yapılmış, iç tutarlılık katsayısı olan Cronbach Alpha değerinin, 92 olarak hesaplandığı tespit edilmiştir.

\section{Verilerin Çözümlenmesi}

Ölçeklerden elde edilen veriler bilgisayar ortamında SPSS paket programı yardımıyla çözümlenmiștir. Ölçeğin birinci bölümüyle ilgili verilere ilişkin frekans ve yüzde dağılımı alınmış, öğretmenlerin tutumlarının ve algılamalarının belirlenmesine yönelik olarak aritmetik ortalama ve standart sapma, tutumlar arasında farklılı̆̆ı ortaya koyabilmek için ikili karşılaştırmalarda dağılım durumuna göre " $\mathrm{t}$ " testi ve Mann Whitney-u testi, ikiden fazla değişken gruplarının karşılaştırılmasında dağılım durumuna göre tek yönlü varyans analizi (ANOVA) kullanılmıştır. Farklılığın anlamlı bulunması durumunda Scheffe (Çoklu Karșllaştırma) testi uygulanmıştır. Yönetim ve öğretmenleri etkileme becerisi arasındaki ilişkileri tespit etmek için Pearson çarpım moment korelasyon analizi yapılmıştır. Görüșler arasında anlamlı bir farklılık olup olmadığı $\alpha<0.05$ anlamlılık düzeyinde test edilmiştir

\section{Bulgular}

Araştırmanın bu bölümünde araștırmada kullanılan ölçeklere verilen cevapların araștırma soruları doğrultusunda analizleri yapılmıştır. Ölçek alt boyutları ile toplam puanları için $\overline{\mathrm{X}}$, ss değerleri ile farklılaşma analizleri, ardından ölçek boyutları arasındaki ilişkileri gösteren korelasyon analizi sunulmuștur.

\section{Öğretmenlerin Okul Müdürlerinde Algıladıkları Yönetim Becerileri Düzeyleri}

Öğretmenlerin okul müdürlerinde algıladıkları yönetim becerileri düzeylerinin madde puan ortalaması ve standart sapma değerleri Tablo 2'de verilmektedir.

Tablo 2. Yönetim Becerileri Ölçeğinin Aritmetik Ortalama, Standart Sapma, Değerleri

\begin{tabular}{lcccc}
\hline Boyut & $\mathrm{N}$ & $\overline{\mathrm{X}}$ & $\mathrm{Ss}$ & Madde Sayısı \\
\hline İnisiyatif alma & 155 & 4,36 & 4,03 & 8 \\
Sorumluluk alma & 155 & 4,30 & 5,74 & 13 \\
Teknik Beceriler & 155 & 4,31 & 2,62 & 5 \\
Diğer Beceriler & 155 & 4,40 & 2,16 & 4 \\
Nitelik & 155 & 4,44 & 2,17 & 4 \\
Yönetim Becerileri Ölçeği & 155 & 4,35 & 14,77 & 34 \\
\hline
\end{tabular}

Tablo 2'de görüldüğü üzere, öğretmenlerin yönetim becerileri ölçeği madde puan ortalaması $\overline{\mathrm{X}}=4,35$ standart sapması ss=14,77 olarak belirlenmiștir. İnisiyatif alma alt boyutu madde puan ortalamasının $\bar{X}=4,30$ standart sapması ss=4,03 olduğu, 
sorumluluk alma alt boyutu madde puan ortalaması $\overline{\mathrm{X}}=4,30$ standart sapması ss=5,74 olduğu, teknik beceriler alt boyutu madde puan ortalaması $\overline{\mathrm{X}}=4,31$ standart sapması ss $=2,62$ olduğu, diğer becerilerin madde puan ortalaması $\bar{X}=4,40$ standart sapması $\mathrm{ss}=2,16$ olduğu, nitelik becerilerinin madde puan ortalaması $\overline{\mathrm{X}}=4,44$ standart sapması $s s=2,17$ olduğu görülmektedir. Bu durum öğretmenlerin okul müdürlerinde algıladıkları yönetim becerilerinin yüksek düzeyde olduğunu göstermektedir.

\section{Düzeyleri}

Öğretmenlerin Demografik Durumlarına Göre Yönetim Becerileri Algılama

Tablo 3. Okul Müdürlerinin Yönetim Becerilerini Algılama Düzeylerinin Cinsiyet Faktörüne Göre t Testi Sonuçları

\begin{tabular}{|c|c|c|c|c|c|c|c|c|}
\hline \multirow[b]{2}{*}{ Ölçek } & \multirow{2}{*}{ Cinsiyet } & \multirow{2}{*}{$\mathbf{n}$} & \multirow{2}{*}{$x$} & \multirow{2}{*}{ sS } & \multirow{2}{*}{ Sh } & \multicolumn{3}{|c|}{ t Testi } \\
\hline & & & & & & $\mathbf{t}$ & sd & $p$ \\
\hline \multirow{2}{*}{$\begin{array}{l}\text { İnisiyatif } \\
\text { alma }\end{array}$} & Erkek & 3 & 34,00 & 4,359 & 2,517 &,- 399 & 153 & 691 \\
\hline & Kadın & 152 & 34,94 & 4,043 & ,328 & & & \\
\hline \multirow{2}{*}{$\begin{array}{l}\text { Sorumluluk } \\
\text { alma }\end{array}$} & Erkek & 3 & 56,33 & 4,619 & 2,667 & ,125 & 153 & 901 \\
\hline & Kadın & 152 & 55,91 & 5,774 & ,468 & & & \\
\hline \multirow{2}{*}{$\begin{array}{l}\text { Teknik } \\
\text { beceriler }\end{array}$} & Erkek & 3 & 21,00 & 2,000 & 1,155 &,- 360 & 153 & ,720 \\
\hline & Kadın & 152 & 21,55 & 2,644 & ,214 & & & \\
\hline \multirow{2}{*}{$\begin{array}{l}\text { Diğer } \\
\text { beceriler }\end{array}$} & Erkek & 3 & 16,00 & 1,000 & ,577 & $-1,309$ & 153 & 193 \\
\hline & Kadın & 152 & 17,64 & 2,167 & ,176 & & & \\
\hline \multirow[t]{2}{*}{ Nitelik } & Erkek & 3 & 17,67 & 1,528 & ,882 &,- 081 & 153 & ,936 \\
\hline & Kadın & 152 & 17,77 & 2,191 & ,178 & & & \\
\hline \multirow[t]{2}{*}{ Toplam } & Erkek & 3 & 145,00 & 12,166 & 7,024 &,- 327 & 153 & ,744 \\
\hline & Kadın & 152 & 147,82 & 14,852 & 1,205 & & & \\
\hline
\end{tabular}

Tablo 3'te görüldüğü üzere, öğretmenlerin okul müdürlerinin yönetim becerilerine ilişkin görüşleri, cinsiyet değişkenine göre anlamlı ölçüde farklılaşmamaktadır.

Tablo 4. Okul Müdürlerinin Yönetim Becerilerini Algılama Düzeylerinin Medeni Durum Faktörüne Göre t Testi Sonuçları

\begin{tabular}{|c|c|c|c|c|c|c|c|c|}
\hline \multirow[b]{2}{*}{ ölçek } & \multirow{2}{*}{$\begin{array}{l}\text { Medeni } \\
\text { Durum }\end{array}$} & \multirow{2}{*}{$\mathbf{n}$} & \multirow{2}{*}{$\bar{x}$} & \multirow{2}{*}{ ss } & \multirow{2}{*}{ Sh } & \multicolumn{3}{|c|}{ t Testi } \\
\hline & & & & & & t & sd & $p$ \\
\hline \multirow{2}{*}{$\begin{array}{l}\text { İnisiyatif } \\
\text { alma }\end{array}$} & Evli & 100 & 34,96 & 3,345 & ,335 & 155 & 153 & 877 \\
\hline & Bekar & 55 & 34,85 & 5,093 & 687 & & & \\
\hline \multirow{2}{*}{$\begin{array}{l}\text { Sorumluluk } \\
\text { alma }\end{array}$} & Evli & 100 & 55,59 & 5,977 & ,598 &,- 972 & 153 & ,332 \\
\hline & Bekar & 55 & 56,53 & 5,287 & ,713 & & & \\
\hline \multirow{2}{*}{$\begin{array}{l}\text { Teknik } \\
\text { beceriler }\end{array}$} & Evli & 100 & 21,52 & 2,468 & 247 &,- 140 & 153 & 889 \\
\hline & Bekar & 55 & 21,58 & 2,923 & ,394 & & & \\
\hline \multirow{2}{*}{$\begin{array}{l}\text { Diğer } \\
\text { beceriler }\end{array}$} & $\begin{array}{l}\text { Evli } \\
\end{array}$ & 100 & 17,71 & 1,996 & 200 & ,753 & 153 & ,452 \\
\hline & Bekar & 55 & 17,44 & 2,440 & ,329 & & & \\
\hline
\end{tabular}


Cebrail Haveydi, Yusuf Alpaydın, “Okulöncesi Eğitim Kurumu Müdürlerinin Yönetim Becerileri ile Etkileme Güçleri Arasındaki İlişkilerin Öğretmen Görüşlerine Göre İncelenmesi”,

İstanbul Gelişim Üniversitesi Sosyal Bilimler Dergisi, 6 (1), Nisan 2019, ss. 120-144

\begin{tabular}{llrrrrrrr}
\hline Nitelik & Evli & 100 & 17,71 & 2,076 &, 208 &,- 444 & 153 &, 658 \\
& Bekar & 55 & 17,87 & 2,365 &, 319 & & & \\
\hline \multirow{2}{*}{ Toplam } & Evli & 100 & 147,49 & 13,851 & 1,385 &,- 315 & 153 &, 753 \\
& Bekar & 55 & 148,27 & 16,450 & 2,218 & & & \\
\hline
\end{tabular}

Tablo 4'te görüldüğü üzere, öğretmenlerin okul müdürlerinin yönetim becerilerine ilişkin görüşleri medeni durum değişkenine göre anlamlı ölçüde farklılaşmamaktadır.

Tablo 5. Okul Müdürlerinin Yönetim Becerilerini Algllama Düzeylerinin Yaş Faktörüne Göre Anova Testi Sonuçları

\begin{tabular}{|c|c|c|c|c|c|c|c|c|c|c|}
\hline & \multicolumn{4}{|c|}{$f, \overline{\mathrm{X}}$ ve $S S$ Değerleri } & \multicolumn{6}{|c|}{ ANOVA Sonuçları } \\
\hline & Gruplar & $\mathrm{N}$ & $\overline{\bar{x}}$ & Ss & Var.K. & $K T$ & $S d$ & KO & $\mathrm{F}$ & $p$ \\
\hline \multirow[t]{4}{*}{$\begin{array}{l}\text { İns. } \\
\text { Alma }\end{array}$} & $\begin{array}{l}20-25 \\
\text { yaş }\end{array}$ & 37 & 35,03 & 5,052 & G.Arası & 5,317 & 2 & 2,659 & \multirow[t]{4}{*}{, 161 } & \multirow[t]{4}{*}{,851 } \\
\hline & $\begin{array}{l}26-30 \\
\text { yaş }\end{array}$ & 83 & 34,76 & 4,244 & G.İçi & 2503,754 & 152 & 16,472 & & \\
\hline & $\begin{array}{l}31 \text { yaș } \\
\text { ve } \\
\text { üzeri }\end{array}$ & 35 & 35,20 & 1,779 & Toplam & 2509,071 & 154 & & & \\
\hline & Toplam & 155 & 34,92 & 4,036 & & & & & & \\
\hline \multirow[t]{4}{*}{$\begin{array}{l}\text { Sor. } \\
\text { Alma }\end{array}$} & $\begin{array}{l}20-25 \\
\text { yaş }\end{array}$ & 37 & 56,38 & 4,591 & G.Arası & 104,812 & 2 & 52,406 & \multirow[t]{4}{*}{1,602} & \multirow[t]{4}{*}{205} \\
\hline & $\begin{array}{l}26-30 \\
\text { yaş }\end{array}$ & 83 & 56,36 & 6,629 & G.İçi & 4972,259 & 152 & 32,712 & & \\
\hline & $\begin{array}{l}31 \text { yaş } \\
\text { ve } \\
\text { üzeri }\end{array}$ & 35 & 54,40 & 4,237 & Toplam & 5077,071 & 154 & & & \\
\hline & Toplam & 155 & 55,92 & 5,742 & & & & & & \\
\hline \multirow[t]{4}{*}{$\begin{array}{l}\text { Tek. } \\
\text { Bec. }\end{array}$} & $\begin{array}{l}20-25 \\
\text { yaş }\end{array}$ & 37 & 21,84 & 2,511 & G.Arası & 7,344 & 2 & 3,672 & \multirow[t]{4}{*}{,528 } & \multirow[t]{4}{*}{,591 } \\
\hline & $\begin{array}{l}26-30 \\
\text { yaş }\end{array}$ & 83 & 21,55 & 2,889 & G.İçi & 1057,133 & 152 & 6,955 & & \\
\hline & $\begin{array}{l}31 \text { yaş } \\
\text { ve } \\
\text { üzeri }\end{array}$ & 35 & 21,20 & 2,069 & Toplam & 1064,477 & 154 & & & \\
\hline & Toplam & 155 & 21,54 & 2,629 & & & & & & \\
\hline \multirow[t]{4}{*}{$\begin{array}{l}\text { Diğ. } \\
\text { Bec. }\end{array}$} & $\begin{array}{l}20-25 \\
\text { yaş }\end{array}$ & 37 & 17,68 & 2,122 & G.Arası & 3,657 & 2 & 1,829 & \multirow[t]{4}{*}{,389 } & \multirow[t]{4}{*}{679} \\
\hline & $\begin{array}{l}26-30 \\
\text { yaş }\end{array}$ & 83 & 17,48 & 2,441 & G.İçi & 715,117 & 152 & 4,705 & & \\
\hline & $\begin{array}{l}31 \text { yaș } \\
\text { ve } \\
\text { üzeri }\end{array}$ & 35 & 17,86 & 1,375 & Toplam & 718,774 & 154 & & & \\
\hline & Toplam & 155 & 17,61 & 2,160 & & & & & & \\
\hline Nite. & $\begin{array}{l}20-25 \\
\text { yaș }\end{array}$ & 37 & 17,89 & 2,183 & G.Arası & 3,678 & 2 & 1,839 & ,385 & 681 \\
\hline
\end{tabular}


Cebrail Haveydi, Yusuf Alpaydın, “Okulöncesi Eğitim Kurumu Müdürlerinin Yönetim Becerileri ile Etkileme Güçleri Arasındaki İlişkilerin Öğretmen Görüşlerine Göre İncelenmesi",

İstanbul Gelişim Üniversitesi Sosyal Bilimler Dergisi, 6 (1), Nisan 2019, ss. 120-144

\begin{tabular}{|c|c|c|c|c|c|c|c|c|c|c|}
\hline & $\begin{array}{l}26-30 \\
\text { yaș }\end{array}$ & 83 & 17,63 & 2,478 & G.İçi & 725,961 & 152 & 4,776 & & \\
\hline & $\begin{array}{l}31 \text { yaş } \\
\text { ve } \\
\text { üzeri }\end{array}$ & 35 & 17,97 & 1,224 & Toplam & 729,639 & 154 & & & \\
\hline & Toplam & 155 & 17,77 & 2,177 & & & & & & \\
\hline \multirow[t]{4}{*}{ Top } & $\begin{array}{l}20-25 \\
\text { yaș }\end{array}$ & 37 & 148,81 & 13,988 & G.Arası & 85,695 & 2 & 42,848 & \multirow[t]{4}{*}{ 194 } & \multirow[t]{4}{*}{,824 } \\
\hline & $\begin{array}{l}26-30 \\
\text { yaş }\end{array}$ & 83 & 147,78 & 17,282 & G.İçi & 33541,943 & 152 & 220,671 & & \\
\hline & $\begin{array}{l}31 \text { yaş } \\
\text { ve } \\
\text { üzeri }\end{array}$ & 35 & 146,63 & 7,681 & Toplam & 33627,639 & 154 & & & \\
\hline & Toplam & 155 & 147,77 & 14,777 & & & & & & \\
\hline
\end{tabular}

Tablo 5'te görüldüğü üzere, öğretmenlerin okul müdürlerinin yönetim becerilerine ilişkin görüşleri, yaş değişkenine göre anlamlı ölçüde farklılaşmamaktadır

Tablo 6. Okul Müdürlerinin Yönetim Becerilerini Algılama Düzeylerinin Kıdemlerine Göre t Testi Sonuçları

\begin{tabular}{|c|c|c|c|c|c|c|c|c|}
\hline & \multirow{2}{*}{ Kıdem } & \multirow{2}{*}{ n } & \multirow{2}{*}{$\bar{x}$} & \multirow{2}{*}{ ss } & \multirow{2}{*}{ Sh } & \multicolumn{3}{|c|}{ t Testi } \\
\hline Ölçek & & & & & & $t$ & sd & $p$ \\
\hline \multirow{2}{*}{$\begin{array}{l}\text { İnisiyatif } \\
\text { alma }\end{array}$} & $1-5 \mathrm{yll}$ & 115 & 34,84 & 4,493 & ,419 & \multirow[t]{2}{*}{,- 413} & \multirow[t]{2}{*}{153} & \multirow[t]{2}{*}{,680 } \\
\hline & $\begin{array}{l}6 \text { yıl ve } \\
\text { üzeri }\end{array}$ & 40 & 35,15 & 2,293 & ,363 & & & \\
\hline \multirow{2}{*}{$\begin{array}{l}\text { Sorumluluk } \\
\text { alma }\end{array}$} & $1-5$ yll & 115 & 56,40 & 6,176 & ,576 & \multirow[t]{2}{*}{1,767} & \multirow[t]{2}{*}{153} & \multirow[t]{2}{*}{,079 } \\
\hline & $\begin{array}{l}6 \text { yıl ve } \\
\text { üzeri }\end{array}$ & 40 & 54,55 & 4,012 & 634 & & & \\
\hline \multirow{2}{*}{$\begin{array}{l}\text { Teknik } \\
\text { beceriler }\end{array}$} & $1-5$ yll & 115 & 21,66 & 2,794 & ,261 & \multirow[t]{2}{*}{,955 } & \multirow[t]{2}{*}{153} & \multirow[t]{2}{*}{,341 } \\
\hline & $\begin{array}{l}6 \text { yıl ve } \\
\text { üzeri }\end{array}$ & 40 & 21,20 & 2,078 & 329 & & & \\
\hline \multirow{2}{*}{$\begin{array}{l}\text { Diğer } \\
\text { beceriler }\end{array}$} & $1-5$ yll & 115 & 17,62 & 2,372 & ,221 & \multirow[t]{2}{*}{,044 } & \multirow[t]{2}{*}{153} & \multirow[t]{2}{*}{,965 } \\
\hline & $\begin{array}{l}6 \text { yll ve } \\
\text { üzeri }\end{array}$ & 40 & 17,60 & 1,411 & ,223 & & & \\
\hline \multirow[t]{2}{*}{ Nitelik } & $1-5$ yll & 115 & 17,72 & 2,423 & ,226 & \multirow[t]{2}{*}{,- 445} & \multirow[t]{2}{*}{153} & \multirow[t]{2}{*}{657} \\
\hline & $\begin{array}{l}6 \text { yıl ve } \\
\text { üzeri }\end{array}$ & 40 & 17,90 & 1,236 & ,195 & & & \\
\hline \multirow[t]{2}{*}{ Toplam } & $1-5$ yll & 115 & 148,24 & 16,526 & 1,541 & \multirow[t]{2}{*}{,678 } & \multirow[t]{2}{*}{153} & \multirow[t]{2}{*}{,499 } \\
\hline & $\begin{array}{l}6 \text { yıl ve } \\
\text { üzeri }\end{array}$ & 40 & 146,40 & 7,834 & 1,239 & & & \\
\hline
\end{tabular}

Tablo 6'da görüldüğü üzere, öğretmenlerin okul müdürlerinin yönetim becerilerine ilişkin görüşleri, kıdem durumu değişkenine göre anlamlı ölçüde farklılaşmamaktadır. 
Tablo 7. Okul Müdürlerinin Yönetim Becerilerini Algllama Düzeylerinin Okuldaki Çalışma Süresine Göre Anova Testi Sonuçları

\begin{tabular}{|c|c|c|c|c|c|c|c|c|c|c|}
\hline & \multicolumn{4}{|c|}{$f, \overline{\mathrm{X}}$ ve $S S$ Değerleri } & \multicolumn{6}{|c|}{ ANOVA Sonuçları } \\
\hline & Gruplar & $\mathrm{N}$ & $\bar{x}$ & Ss & Var.K. & $K T$ & $S d$ & KO & $\mathrm{F}$ & $\bar{p}$ \\
\hline \multirow{4}{*}{$\begin{array}{l}\text { İns. } \\
\text { Alma }\end{array}$} & 1 yll & 34 & 35,50 & 3,808 & G.Arası & 22,310 & 2 & 11,155 & \multirow[t]{4}{*}{ 682 } & \multirow[t]{4}{*}{,507 } \\
\hline & 2 yil & 82 & 34,59 & 4,058 & G.İçi & 2486,761 & 152 & 16,360 & & \\
\hline & $\begin{array}{l}3 \text { yıl ve } \\
\text { üzeri }\end{array}$ & 39 & 35,13 & 4,213 & & 2509,071 & 154 & & & \\
\hline & Toplam & 155 & 34,92 & 4,036 & & & & & & \\
\hline \multirow{4}{*}{$\begin{array}{l}\text { Sor. } \\
\text { Alma }\end{array}$} & $1 \mathrm{yll}$ & 34 & 56,38 & 3,846 & G.Arası & 21,545 & 2 & 10,772 & \multirow[t]{4}{*}{324} & \multirow[t]{4}{*}{,724 } \\
\hline & 2 yll & 82 & 55,57 & 6,680 & G.İçi & 5055,526 & 152 & 33,260 & & \\
\hline & $\begin{array}{l}3 \text { yıl ve } \\
\text { üzeri }\end{array}$ & 39 & 56,26 & 5,009 & & 5077,071 & 154 & & & \\
\hline & Toplam & 155 & 55,92 & 5,742 & & & & & & \\
\hline \multirow{4}{*}{$\begin{array}{l}\text { Tek. } \\
\text { Bec. }\end{array}$} & 1 yll & 34 & 22,15 & 1,635 & G.Arası & 42,510 & 2 & 21,255 & \multirow[t]{4}{*}{3,161} & \multirow[t]{4}{*}{045} \\
\hline & 2 yll & 82 & 21,05 & 2,739 & G.İçi & 1021,967 & 152 & 6,723 & & \\
\hline & $\begin{array}{l}3 \text { yıl ve } \\
\text { üzeri }\end{array}$ & 39 & 22,05 & 2,929 & & 1064,477 & 154 & & & \\
\hline & Toplam & 155 & 21,54 & 2,629 & & & & & & \\
\hline \multirow{4}{*}{$\begin{array}{l}\text { Diğ. } \\
\text { Bec. }\end{array}$} & 1 yl & 34 & 17,97 & 1,114 & G.Arası & 23,857 & 2 & 11,929 & \multirow[t]{4}{*}{2,609} & \multirow[t]{4}{*}{,077 } \\
\hline & 2 yll & 82 & 17,78 & 2,419 & G.İçi & 694,917 & 152 & 4,572 & & \\
\hline & $\begin{array}{l}3 \text { yıl ve } \\
\text { üzeri }\end{array}$ & 39 & 16,95 & 2,176 & & 718,774 & 154 & & & \\
\hline & Toplam & 155 & 17,61 & 2,160 & & & & & & \\
\hline \multirow[t]{4}{*}{ Nite. } & 1 yll & 34 & 17,76 & 1,437 & G.Arası & 5,426 & 2 & 2,713 & \multirow[t]{4}{*}{,569 } & \multirow[t]{4}{*}{,567 } \\
\hline & 2 yil & 82 & 17,91 & 2,379 & G.İçi & 724,212 & 152 & 4,765 & & \\
\hline & $\begin{array}{l}3 \text { yıl ve } \\
\text { üzeri }\end{array}$ & 39 & 17,46 & 2,281 & & 729,639 & 154 & & & \\
\hline & Toplam & 155 & 17,77 & 2,177 & & & & & & \\
\hline \multirow[t]{4}{*}{ Top } & 1 yll & 34 & 149,76 & 8,856 & G.Arası & 197,225 & 2 & 98,612 & \multirow[t]{4}{*}{,448 } & \multirow[t]{4}{*}{640} \\
\hline & 2 yıl & 82 & 146,90 & 16,499 & G.İçi & 33430,414 & 152 & 219,937 & & \\
\hline & $\begin{array}{l}3 \text { yıl ve } \\
\text { üzeri }\end{array}$ & 39 & 147,85 & 15,212 & & 33627,639 & 154 & & & \\
\hline & Toplam & 155 & 147,77 & 14,777 & & & & & & \\
\hline
\end{tabular}

Tablo 7'de görüldüğü üzere, öğretmenlerin okul müdürlerinin yönetim becerilerine ilişkin görüşlerinin okuldaki çalışma süresi değişkenine göre anlamlı bir farklılık gösterip göstermediğini belirlemek amacıyla yapılan tek yönlü varyans analizi (ANOVA) sonrasında, grupların aritmetik ortalamaları arasında teknik beceriler alt boyutunda anlamlı farklılık bulunurken $(\mathrm{F}=3,161 ; \mathrm{p}<.05)$ toplam ölçek ve diğer alt 
boyutlarda anlamlı farklılık bulunmamıştır. Farklılığın hangi gruplardan kaynaklandığını belirlemek üzere tamamlayıcı Scheffe testi uygulanmıș, test sonuçları tabloda verilmiștir $(F=, 682 ; p>.05 ; F=, 324 ; p>.05 ; F=2,609 ; p>.05 ; F=, 569 ; p>.05 ; F=, 448 ; p>.05)$.

Tablo 8. Okuldaki Çalışma Süresi Göre Scheffe Testi Sonuçları

\begin{tabular}{|c|c|c|c|c|c|}
\hline Ölçek & $\begin{array}{l}\text { Okuldaki } \\
\text { Çalışma Süresi } \\
\text { (i) }\end{array}$ & $\begin{array}{l}\text { Okuldaki } \\
\text { Çalışma Süresi } \\
\text { (j) }\end{array}$ & $i-j$ & $S h_{\bar{x}}$ & $p$ \\
\hline \multirow{6}{*}{$\begin{array}{l}\text { Teknik } \\
\text { Beceriler }\end{array}$} & \multirow{2}{*}{$1 \mathrm{yll}$} & 2 yıl & 1,098 & ,529 & ,019 \\
\hline & & 3 yıl ve üzeri &, 096 & ,608 & ,988 \\
\hline & \multirow{2}{*}{$2 \mathrm{yll}$} & $1 \mathrm{yll}$ & $-1,098$ & ,529 & ,019 \\
\hline & & 3 yll ve üzeri & $-1,003$ & ,504 & 142 \\
\hline & \multirow{2}{*}{3 yıl ve üzeri } & $1 \mathrm{yll}$ &,- 096 & ,608 & ,988 \\
\hline & & $2 \mathrm{yll}$ & 1,003 & ,504 & 142 \\
\hline
\end{tabular}

Tablo 8'de görüldüğü üzere, okuldaki çalıșma süresine göre hangi gruplar arasında farklılaştığını belirlemek üzere yapılan Scheffe testi sonucunda, teknik beceriler alt boyutunda söz konusu farklılığın 1 yıl çalışanlar ile 2 yıl çalışanlar arasında 1 yıl çalışanlar lehine anlamlı farklılık görülmüştür. 1 yıl çalışanlar, yöneticileri daha olumlu değerlendirmektedirler. Diğer grup arasında farklılık yoktur.

Tablo 9. Okul Müdürlerinin Yönetim Becerilerini Algılama Düzeylerinin Öğrenim Durumu Faktörüne Göre t Testi Sonuçları

\begin{tabular}{|c|c|c|c|c|c|c|c|c|}
\hline \multirow[b]{2}{*}{ Ölçek } & \multirow{2}{*}{$\begin{array}{l}\text { Öğrenim } \\
\text { Durumu }\end{array}$} & \multirow{2}{*}{$\mathrm{n}$} & \multirow{2}{*}{$\bar{x}$} & \multirow{2}{*}{ ss } & \multirow{2}{*}{ Sh } & \multicolumn{3}{|c|}{ t Testi } \\
\hline & & & & & & t & sd & $p$ \\
\hline \multirow{2}{*}{$\begin{array}{l}\text { İnisiyatif } \\
\text { alma }\end{array}$} & Önlisans & 66 & 35,05 & 4,291 & ,528 & \multirow[t]{2}{*}{,325 } & \multirow[t]{2}{*}{153} & \multirow[t]{2}{*}{,745 } \\
\hline & Lisans & 89 & 34,83 & 3,859 & ,409 & & & \\
\hline \multirow{2}{*}{$\begin{array}{l}\text { Sorumluluk } \\
\text { alma }\end{array}$} & Önlisans & 66 & 56,21 & 6,111 &, 752 & \multirow[t]{2}{*}{,539 } & \multirow[t]{2}{*}{153} & \multirow[t]{2}{*}{, 590} \\
\hline & Lisans & 89 & 55,71 & 5,478 & ,581 & & & \\
\hline \multirow{2}{*}{$\begin{array}{l}\text { Teknik } \\
\text { beceriler }\end{array}$} & Önlisans & 66 & 21,32 & 2,952 & ,363 & \multirow[t]{2}{*}{,- 912} & \multirow[t]{2}{*}{153} & \multirow[t]{2}{*}{,363 } \\
\hline & Lisans & 89 & 21,71 & 2,365 & ,251 & & & \\
\hline \multirow{2}{*}{$\begin{array}{l}\text { Diğer } \\
\text { beceriler }\end{array}$} & Önlisans & 66 & 17,45 & 2,609 &, 321 & \multirow[t]{2}{*}{$\begin{array}{l}-, 785 \\
\end{array}$} & \multirow[t]{2}{*}{153} & \multirow[t]{2}{*}{,434 } \\
\hline & Lisans & 89 & 17,73 & 1,763 & ,187 & & & \\
\hline \multirow[t]{2}{*}{ Nitelik } & Önlisans & 66 & 17,86 & 2,683 &, 330 & \multirow[t]{2}{*}{471} & \multirow[t]{2}{*}{153} & \multirow[t]{2}{*}{,638 } \\
\hline & Lisans & 89 & 17,70 & 1,722 & ,182 & & & \\
\hline \multirow[t]{2}{*}{ Toplam } & Önlisans & 66 & 147,89 & 16,999 & 2,092 & \multirow[t]{2}{*}{091} & \multirow[t]{2}{*}{153} & \multirow[t]{2}{*}{,927 } \\
\hline & Lisans & 89 & 147,67 & 12,988 & 1,377 & & & \\
\hline
\end{tabular}

Tablo 9'da da görüldüğü üzere, öğretmenlerin okul müdürlerinin yönetim becerilerine ilişkin görüşleri, öğrenim durumu değişkenine göre anlamlı ölçüde farklılaşmamaktadır. 
Tablo 10. Okul Müdürlerinin Yönetim Becerilerini Algılama Düzeylerinin Okul Türüne Göre t Testi Sonuçları

\begin{tabular}{|c|c|c|c|c|c|c|c|c|}
\hline \multirow[t]{2}{*}{ ölçek } & \multirow{2}{*}{$\begin{array}{l}\text { Okul } \\
\text { Türü }\end{array}$} & \multirow{2}{*}{$\mathbf{n}$} & \multirow{2}{*}{$\bar{x}$} & \multirow{2}{*}{ sS } & \multirow{2}{*}{ Sh } & \multicolumn{3}{|c|}{ t Testi } \\
\hline & & & & & & $\mathbf{t}$ & sd & $p$ \\
\hline \multirow{2}{*}{$\begin{array}{l}\text { İnisiyatif } \\
\text { alma }\end{array}$} & Devlet & 112 & 34,60 & 4,581 & 433, & \multirow{2}{*}{$\begin{array}{r}- \\
1,623\end{array}$} & \multirow[t]{2}{*}{153} & \multirow[t]{2}{*}{ 107 } \\
\hline & Özel & 43 & 35,77 & 1,811 & ,276 & & & \\
\hline \multirow{2}{*}{$\begin{array}{l}\text { Sorumluluk } \\
\text { alma }\end{array}$} & Devlet & 112 & 55,35 & 6,534 & 617 & \multirow{2}{*}{ 2,030 } & \multirow[t]{2}{*}{153} & \multirow[t]{2}{*}{,044 } \\
\hline & Özel & 43 & 57,42 & 2,206 & ,336 & & & \\
\hline \multirow{2}{*}{$\begin{array}{l}\text { Teknik } \\
\text { beceriler }\end{array}$} & Devlet & 112 & 21,15 & 2,942 & ,278 & \multirow{2}{*}{3,062} & \multirow[t]{2}{*}{153} & \multirow[t]{2}{*}{,003 } \\
\hline & Özel & 43 & 22,56 & 1,007 & ,154 & & & \\
\hline \multirow{2}{*}{$\begin{array}{l}\text { Diğer } \\
\text { beceriler }\end{array}$} & Devlet & 112 & 17,55 & 2,456 & 232 & \multirow[t]{2}{*}{,- 551} & \multirow[t]{2}{*}{153} & \multirow[t]{2}{*}{,583 } \\
\hline & Özel & 43 & 17,77 & 1,065 & ,162 & & & \\
\hline \multirow[t]{2}{*}{ Nitelik } & Devlet & 112 & 17,74 & 2,463 & ,233 & \multirow[t]{2}{*}{,- 245} & \multirow[t]{2}{*}{153} & \multirow[t]{2}{*}{ 806 } \\
\hline & Özel & 43 & 17,84 & 1,153 & 176, & & & \\
\hline \multirow[t]{2}{*}{ Toplam } & Devlet & 112 & 146,39 & 17,059 & 1,612 & \multirow{2}{*}{$\begin{array}{r}- \\
1,885\end{array}$} & \multirow[t]{2}{*}{153} & \multirow[t]{2}{*}{,061 } \\
\hline & Özel & 43 & 151,35 & 3,657 & ,558 & & & \\
\hline
\end{tabular}

Tablo 10'da da görüldüğü üzere, öğretmenlerin okul müdürlerinin yönetim becerilerine ilişkin görüșlerinin okul türü değişkenine göre anlamlı bir farklılık gösterip göstermediğini belirlemek amacıyla yapılan bağımsız grup t testi sonucunda sorumluluk alma ve teknik beceriler alt boyutlarında anlamlı farklılık görülürken $(t=-2,030 ; p<.05$; $\mathrm{t}=-3,062 ; \mathrm{p}<.05)$ toplam ölçek ile diğer alt boyutlarda anlamlı farklılık bulunmamıştır $(\mathrm{t}=-$ 1,623;p>.05; $\mathrm{t}=-, 551 ; \mathrm{p}>.05 ; \mathrm{t}=-, 245 ; \mathrm{p}>.05 ; \mathrm{t}=-1,885 ; \mathrm{p}>.05$ ). İnisiyatif alma, diğer beceriler, nitelik becerileri ve toplam ölçekte okul türüne göre öğretmen görüșleri arasında anlamlı farklılık bulunmazken sorumluluk teknik becerilerde özel okullarda çalıșan öğretmenler resmi okullarda çalışanlar göre daha olumlu değerlendirmelerde bulunmaktadırlar.

Tablo 11. Okul Müdürlerinin Öğretmenleri Etkileme Ölçeğinin Aritmetik Ortalama, Standart Sapma, Değerleri

\begin{tabular}{lcccc}
\hline Boyut & N & $\overline{\mathbf{X}}$ & Ss & Madde Sayısı \\
\hline Yetkiyle Etkileme & 155 & 2,74 & 7,40 & 10 \\
Uzmanlıkla Etkileme & 155 & 4,06 & 6,44 & 10 \\
Kişilikle Etkileme & 155 & 4,27 & 6,01 & 10 \\
Toplam Ölçek & 155 & 3,69 & 15,26 & 30 \\
\hline
\end{tabular}

Tabloda 11'de görüldügü üzere, öğretmen görüşlerine göre okul müdürlerinin öğretmenleri etkileme ölçeğinin madde puan ortalaması $\bar{X}=3,69$ standart sapması ss=15,26; yetki yoluyla etkileme alt boyutu puanların madde puan ortalaması $\bar{X}=2,74$ standart sapması ss=7,40; Uzmanlık gücüyle etkileme alt boyutu puanlarının madde 
puan ortalaması $\bar{X}=4,06$ standart sapması ss=6,44; Kişilik yoluyla etkilemesi puanlarının madde puan ortalaması $\overline{\mathrm{X}}=4,27$ standart sapması ss $=6,01$; olarak belirlenmiştir. En yüksek etkileme tarzının kişilikle etkileme, daha sonra uzmanlıkla etkileme ve en az ise yetkiyle etkileme olduğu görülmüștür.

Tablo 12. Okul Müdürlerinin Öğretmenleri Etkilemelerinin Öğretmenlerin Cinsiyet Faktörüne Göre t Testi Sonuçları

\begin{tabular}{|c|c|c|c|c|c|c|c|c|}
\hline \multirow{2}{*}{ Puan } & \multirow{2}{*}{ Cinsiyet } & \multirow{2}{*}{$N$} & \multirow{2}{*}{$\overline{\mathrm{X}}$} & \multirow{2}{*}{$S S$} & \multirow{2}{*}{$\mathrm{Sh}_{\overline{\mathrm{x}}}$} & \multicolumn{3}{|c|}{$t$ Testi } \\
\hline & & & & & & $t$ & sd & $\mathrm{p}$ \\
\hline \multirow{2}{*}{ Yetki } & Erkek & 3 & 26,00 & 4,583 & 2,646 &,- 327 & 153 & ,744 \\
\hline & Kadın & 152 & 27,41 & 7,458 & ,605 & & & \\
\hline \multirow{2}{*}{ Uzmanlık } & Erkek & 3 & 36,00 & 7,211 & 4,163 & $-1,264$ & 153 & 208 \\
\hline & Kadın & 152 & 40,74 & 6,418 & ,521 & & & \\
\hline \multirow{2}{*}{ Kişilik } & Erkek & 3 & 39,33 & 8,145 & 4,702 &,- 996 & 153 & ,321 \\
\hline & Kadın & 152 & 42,82 & 5,978 & , 485 & & & \\
\hline Toplam & Erkek & 3 & 101,33 & 10,263 & 5,925 & $-1,084$ & 153 & ,280 \\
\hline Ölçek & Kadın & 152 & 110,97 & 15,316 & 1,242 & & & \\
\hline
\end{tabular}

Tablo 12'de görüldüğü üzere, öğretmenlerin okul müdürlerinde algıladıkları okul müdürünün öğretmeni etkileme gücü ölçeği puanları, cinsiyet değişkenine göre anlamlı ölçüde farklılaşmamaktadır.

Tablo 13. Okul Müdürlerinin Öğretmenleri Etkilemelerinin Öğretmenlerin Medeni Durum Faktörüne Göre t Testi Sonuçları

\begin{tabular}{|c|c|c|c|c|c|c|c|c|}
\hline \multirow{2}{*}{ Puan } & \multirow{2}{*}{$\begin{array}{l}\text { Medeni } \\
\text { Durum }\end{array}$} & \multirow{2}{*}{$N$} & \multirow{2}{*}{$\overline{\mathrm{X}}$} & \multirow{2}{*}{$S S$} & \multirow{2}{*}{$\mathrm{Sh}_{\overline{\mathrm{x}}}$} & \multicolumn{3}{|c|}{$t$ Testi } \\
\hline & & & & & & $t$ & sd & $\mathrm{p}$ \\
\hline \multirow{2}{*}{ Yetki } & Evli & 100 & 27,78 & 6,813 & 681 & ,890 & 153 & ,375 \\
\hline & Bekar & 55 & 26,67 & 8,398 & 1,132 & & & \\
\hline \multirow{2}{*}{ Uzmanlık } & Evli & 100 & 41,32 & 5,224 &, 522 & 1,771 & 153 & ,079 \\
\hline & Bekar & 55 & 39,42 & 8,119 & 1,095 & & & \\
\hline \multirow{2}{*}{ Kişilik } & Evli & 100 & 43,45 & 4,352 & ,435 & 1,959 & 153 & ,042 \\
\hline & Bekar & 55 & 41,49 & 8,112 & 1,094 & & & \\
\hline Toplam & Evli & 100 & 112,55 & 10,925 & 1,093 & 1,956 & 153 & , 042 \\
\hline Ölçek & Bekar & 55 & 107,58 & 20,733 & 2,796 & & & \\
\hline
\end{tabular}

Tablo 13’te de görüldüğü üzere, öğretmenlerin okul müdürlerinde algıladıkları okul müdürünün öğretmeni etkileme gücü ölçeği puanlarının, medeni durum değişkenine göre anlamlı bir farklılık gösterip göstermediğini belirlemek amacıyla yapılan bağımsız grup $\mathrm{t}$ testi sonucunda, toplam ölçek ve kişilikle etkileme alt boyutunda anlamlı farklılık bulunurken $(\mathrm{t}=1,959 ; \mathrm{p}<.05 ; \mathrm{t}=1,959 ; \mathrm{p}<.05)$ yetki ve uzmanlık gücüyle etkileme alt boyutlarında grupların aritmetik ortalamaları arasında istatistiksel olarak anlamlı farklılık bulunmamıștır ( $\mathrm{t}=, 890 ; \mathrm{p}>.05 ; \mathrm{t}=1,771 ; \mathrm{p}>.05)$. Yetki alt boyutunda evli 
öğretmen görüşleri ile bekâr öğretmen görüşleri arasında anlamlı farklılık görülmemiştir. Bu alt boyutta evli ve bekâr öğretmenler okul yöneticilerinin etkileme becerileri hakkında benzer düşünmektedirler. Uzmanlık gücü, kişilik ve toplam ölçekte ise evli öğretmenler bekâr öğretmenlere göre daha olumlu değerlendirmelerde bulunmuşlardır.

Tablo 14. Okul Müdürlerinin Öğretmenleri Etkilemelerinin Öğretmenlerin Yaşlarına Göre Anova Testi Sonuçları

\begin{tabular}{|c|c|c|c|c|c|c|c|c|c|c|}
\hline & \multicolumn{4}{|c|}{$f, \overline{\mathrm{X}}$ ve $S S$ Değerleri } & \multicolumn{6}{|c|}{ ANOVA Sonuçları } \\
\hline & Gruplar & $\mathrm{N}$ & $\bar{x}$ & Ss & $\begin{array}{l}\text { Var. } \\
\text { K. }\end{array}$ & $K T$ & $S d$ & KO & $\mathrm{F}$ & $p$ \\
\hline \multirow{4}{*}{ Yetki } & $20-25$ yaş & 37 & 26,46 & 8,530 & $\begin{array}{l}\text { G. } \\
\text { Arası }\end{array}$ & 253,984 & 2 & 126,992 & \multirow[t]{4}{*}{$\begin{array}{l}2,35 \\
6\end{array}$} & \multirow[t]{4}{*}{$\begin{array}{l}, 09 \\
8\end{array}$} \\
\hline & 26-30 yaş & 83 & 26,81 & 7,301 & G. İçi & 8192,791 & 152 & 53,900 & & \\
\hline & $\begin{array}{l}31 \text { yaş ve } \\
\text { üzeri }\end{array}$ & 35 & 29,74 & 5,948 & & 8446,774 & 154 & & & \\
\hline & Toplam & 155 & 27,39 & 7,406 & & & & & & \\
\hline \multirow{4}{*}{$\begin{array}{l}\text { Uzmanlık } \\
\text { Gücü }\end{array}$} & $20-25$ yaş & 37 & 40,14 & 6,795 & $\begin{array}{l}\text { G. } \\
\text { Arası }\end{array}$ & 119,033 & 2 & 59,516 & \multirow[t]{4}{*}{$\begin{array}{l}1,44 \\
3\end{array}$} & \multirow[t]{4}{*}{$\begin{array}{l}, 24 \\
0\end{array}$} \\
\hline & $26-30$ yaş & 83 & 41,42 & 6,845 & G. İçi & 6270,451 & 152 & 41,253 & & \\
\hline & $\begin{array}{l}31 \text { yaş ve } \\
\text { üzeri }\end{array}$ & 35 & 39,34 & 4,746 & & 6389,484 & 154 & & & \\
\hline & Toplam & 155 & 40,65 & 6,441 & & & & & & \\
\hline \multirow{4}{*}{ Kişilik } & $20-25$ yaş & 37 & 43,00 & 6,557 & $\begin{array}{l}\text { G. } \\
\text { Arası }\end{array}$ & 45,224 & 2 & 22,612 & \multirow[t]{4}{*}{,623 } & \multirow[t]{4}{*}{$\begin{array}{l}, 53 \\
8\end{array}$} \\
\hline & $26-30$ yaş & 83 & 42,29 & 6,465 & G. İçi & 5519,460 & 152 & 36,312 & & \\
\hline & $\begin{array}{l}31 \text { yaş ve } \\
\text { üzeri }\end{array}$ & 35 & 43,60 & 4,001 & & 5564,684 & 154 & & & \\
\hline & Toplam & 155 & 42,75 & 6,011 & & & & & & \\
\hline \multirow{4}{*}{$\begin{array}{l}\text { ToplamEt } \\
\text { kileme }\end{array}$} & 20-25 yaş & 37 & 109,59 & 17,422 & $\begin{array}{l}\text { G. } \\
\text { Arası }\end{array}$ & 184,790 & 2 & 92,395 & \multirow[t]{4}{*}{,393 } & \multirow[t]{4}{*}{$\begin{array}{l}, 67 \\
6\end{array}$} \\
\hline & $26-30$ yaş & 83 & 110,52 & 16,003 & G. İçi & 35721,185 & 152 & 235,008 & & \\
\hline & $\begin{array}{l}31 \text { yaş ve } \\
\text { üzeri }\end{array}$ & 35 & 112,69 & 10,566 & & 35905,974 & 154 & & & \\
\hline & Toplam & 155 & 110,79 & 15,269 & & & & & & \\
\hline
\end{tabular}

Tablo 14'te görüldüğü üzere, öğretmenlerin okul müdürlerinde algıladıkları okul müdürünün öğretmeni etkileme gücü ölçeği puanları, yaş değişkenine göre anlamlı ölçüde farklılaşmamaktadır. 
Tablo 15. Okul Müdürlerinin Öğretmenleri Etkilemelerinin Öğretmenlerin Kıdemlerine Göre t Testi Sonuçları

\begin{tabular}{|c|c|c|c|c|c|c|c|c|}
\hline \multirow{2}{*}{ Puan } & \multirow{2}{*}{ Kıdem } & \multirow{2}{*}{$N$} & \multirow{2}{*}{$\overline{\mathrm{X}}$} & \multirow{2}{*}{$S S$} & \multirow{2}{*}{$\mathrm{Sh}_{\overline{\mathrm{x}}}$} & \multicolumn{3}{|c|}{$t$ Testi } \\
\hline & & & & & & $\bar{t}$ & $\overline{s d}$ & $\mathrm{p}$ \\
\hline \multirow[b]{2}{*}{ Yetki } & $1-5 \mathrm{yll}$ & 115 & 26,67 & 7,754 & ,723 & $-2,067$ & 153 &, 040 \\
\hline & $\begin{array}{l}6 \text { yll ve } \\
\text { üzeri }\end{array}$ & 40 & 29,45 & 5,914 & ,935 & & & \\
\hline \multirow[b]{2}{*}{ Uzmanlık } & $1-5$ yll & 115 & 40,97 & 6,921 & ,645 & 1,078 & 153 & ,283 \\
\hline & $\begin{array}{l}6 \text { yll ve } \\
\text { üzeri }\end{array}$ & 40 & 39,70 & 4,751 & 751 & & & \\
\hline \multirow[b]{2}{*}{ Kişilik } & $1-5 \mathrm{yll}$ & 115 & 42,49 & 6,587 & ,614 &,- 940 & 153 & ,349 \\
\hline & $\begin{array}{l}6 \text { yil ve } \\
\text { üzeri }\end{array}$ & 40 & 43,53 & 3,876 & 613 & & & \\
\hline \multirow[b]{2}{*}{$\begin{array}{l}\text { Toplam } \\
\text { Ölçek }\end{array}$} & $1-5 \mathrm{yll}$ & 115 & 110,13 & 16,685 & 1,556 &,- 907 & 153 & ,366 \\
\hline & $\begin{array}{l}6 \text { yil ve } \\
\text { üzeri }\end{array}$ & 40 & 112,68 & 10,100 & 1,597 & & & \\
\hline
\end{tabular}

Tablo 15’te görüldüğü üzere, öğretmenlerin okul müdürlerinde algıladıkları okul müdürünün öğretmeni etkileme gücünün, kıdem durumu değişkenine göre anlamlı bir farklılık gösterip göstermediğini belirlemek amacıyla yapılan bağımsız grup $t$ testi sonucunda, yetki yoluyla etkileme alt boyutunda anlamlı farklılık bulunurken $(t=-$ $2,067 ; \mathrm{p}<.05)$ toplam ölçek ile diğer alt boyutlarda grupların aritmetik ortalamaları arasında istatistiksel olarak anlamlı farklılı bulunmamıştır $(\mathrm{t}=1,078 ; \mathrm{p}>.05 ; \mathrm{t}=-$ ,940;p>.05; t=-,907; p>.05). Yetki, alt boyutunda kıdemi fazla olan grup kıdemi az olan gruba göre daha olumlu değerlendirmelerde bulunurken uzmanlık kişilik ve toplam ölçekte öğretmen görüşleri arasında anlamlı farklılık görülmemiştir. Kıdem grupları farklıklarında öğretmenler okul yöneticilerinin etkileme becerileri hakkında benzer düşünmektedirler.

Tablo 16. Okul Müdürlerinin Öğretmenleri Etkilemelerinin Öğretmenlerin Okuldaki Çalışma Süresine Göre Anova Testi Sonuçları

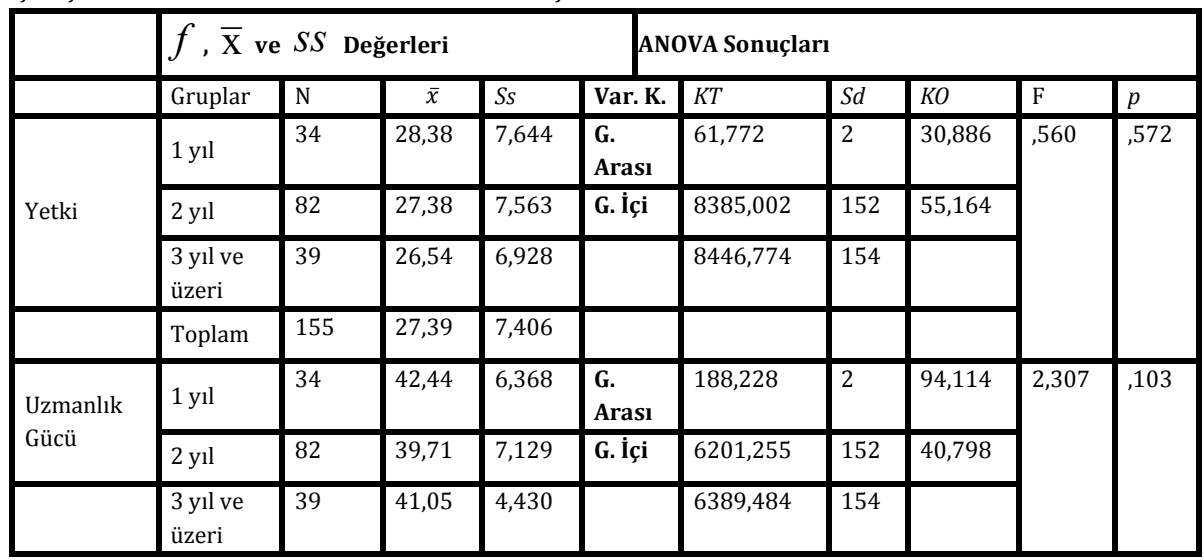




\begin{tabular}{|c|c|c|c|c|c|c|c|c|c|c|}
\hline & Toplam & 155 & 40,65 & 6,441 & & & & & & \\
\hline \multirow{4}{*}{ Kişilik } & 1 yll & 34 & 43,94 & 5,003 & $\begin{array}{l}\text { G. } \\
\text { Arası }\end{array}$ & 75,776 & 2 & 37,888 & \multirow[t]{4}{*}{1,049} & \multirow[t]{4}{*}{,353 } \\
\hline & 2 yıl & 82 & 42,18 & 7,059 & G. İçi & 5488,908 & 152 & 36,111 & & \\
\hline & $\begin{array}{l}\text { yil ve } \\
\text { üzeri }\end{array}$ & 39 & 42,92 & 4,061 & & 5564,684 & 154 & & & \\
\hline & Toplam & 155 & 42,75 & 6,011 & & & & & & \\
\hline \multirow{4}{*}{$\begin{array}{l}\text { Toplam } \\
\text { Etkileme }\end{array}$} & 1 yıl & 34 & 114,76 & 15,471 & $\begin{array}{l}\text { G. } \\
\text { Arası }\end{array}$ & 730,015 & 2 & 365,008 & \multirow[t]{4}{*}{1,577} & \multirow[t]{4}{*}{, 210} \\
\hline & 2 yil & 82 & 109,27 & 17,005 & G. İçi & 35175,959 & 152 & 231,421 & & \\
\hline & $\begin{array}{l}\text { yıl ve } \\
\text { üzeri }\end{array}$ & 39 & 110,51 & 10,070 & & 35905,974 & 154 & & & \\
\hline & $\begin{array}{l}\text { Topla } \\
\text { m }\end{array}$ & 155 & 110,79 & 15,269 & & & & & & \\
\hline
\end{tabular}

Tablo 16'da da görüldüğü üzere, öğretmenlerin okul müdürlerinde algıladıkları okul müdürünün öğretmeni etkileme gücü ölçeği puanlarında, okuldaki çalışma süresi değișkenine göre anlamlı farklılık bulunmamıştır.

Tablo 17. Okul Müdürlerinin Öğretmenleri Etkilemelerinin Öğretmenlerin Öğrenim Durumuna Göre t Testi Sonuçları

\begin{tabular}{|c|c|c|c|c|c|c|c|c|}
\hline \multirow{2}{*}{ Puan } & \multirow{2}{*}{$\begin{array}{l}\text { Öğrenim } \\
\text { Durumu }\end{array}$} & \multirow{2}{*}{$N$} & \multirow{2}{*}{$\overline{\mathrm{x}}$} & \multirow{2}{*}{ SS } & \multirow{2}{*}{$\mathrm{Sh}_{\overline{\mathrm{x}}}$} & \multicolumn{3}{|c|}{$t$ Testi } \\
\hline & & & & & & $\bar{t}$ & $\overline{s d}$ & $\bar{p}$ \\
\hline \multirow{2}{*}{ Yetki } & Önlisans & 66 & 25,47 & 6,592 & 811 & $-2,839$ & 153 & 005 \\
\hline & Lisans & 89 & 28,81 & 7,687 & 815 & & & \\
\hline \multirow{2}{*}{ Uzmanlık } & Önlisans & 66 & 40,56 & 7,374 & 908 &,- 140 & 153 & ,889 \\
\hline & Lisans & 89 & 40,71 & 5,695 & ,604 & & & \\
\hline \multirow{2}{*}{ Kişilik } & Önlisans & 66 & 41,86 & 7,155 & 881 & $-1,597$ & 153 & ,112 \\
\hline & Lisans & 89 & 43,42 & 4,938 &, 523 & & & \\
\hline Toplam & Önlisans & 66 & 107,89 & 17,488 & 2,153 & $-2,052$ & 153 & 042 \\
\hline Ölçek & Lisans & 89 & 112,93 & 13,084 & 1,387 & & & \\
\hline
\end{tabular}

Tablo 17'de görüldüğü üzere, öğretmenlerin okul müdürlerinde algıladıkları okul müdürünün öğretmeni etkileme gücünün, öğrenim durumu değişkenine göre anlamlı bir farklılık gösterip göstermediğini belirlemek amacıyla yapılan bağımsız grup $t$ testi sonucunda, toplam ölçek $(\mathrm{t}=-2,052 ; \mathrm{p}<.05)$ ve yetki yoluyla etkileme alt boyutunda anlamlı farklılık bulunurken $(\mathrm{t}=-2,839 ; \mathrm{p}<.05)$ diğer alt boyutlarda grupların aritmetik ortalamaları arasında istatistiksel olarak anlamlı farklılık bulunmamıştır ( $\mathrm{t}=-, 140 ; \mathrm{p}>.05$; $\mathrm{t}=-1,597 ; \mathrm{p}>.05$ ). Yetki ve toplam ölçekte lisans mezunları okul müdürleri hakkında daha olumlu değerlendirmelerde bulunurken uzmanlık ve kişilik alt boyutunda ise gruplar arasında farklılık bulunmamıștır. 
Tablo 18. Okul Müdürlerinin Öğretmenleri Etkilemelerinin Öğretmenlerin Okul Türüne Göre t Testi Sonuçları

\begin{tabular}{|c|c|c|c|c|c|c|c|c|}
\hline \multirow{2}{*}{ Puan } & \multirow{2}{*}{ Okul Türü } & \multirow{2}{*}{$N$} & \multirow{2}{*}{$\overline{\mathrm{X}}$} & \multirow{2}{*}{$S S$} & \multirow{2}{*}{$\mathrm{Sh}_{\overline{\mathrm{x}}}$} & \multicolumn{3}{|c|}{$t$ Testi } \\
\hline & & & & & & $\bar{t}$ & $\overline{s d}$ & $\overline{\mathrm{p}}$ \\
\hline \multirow{2}{*}{ Yetki } & Devlet & 112 & 27,36 & 7,502 & ,709 & \multirow[t]{2}{*}{-081} & \multirow[t]{2}{*}{153} & \multirow[t]{2}{*}{,936 } \\
\hline & $\overline{\text { Özel }}$ & 43 & 27,47 & 7,235 & 1,103 & & & \\
\hline \multirow{2}{*}{ Uzmanlık } & Devlet & 112 & 39,92 & 6,329 & ,598 & \multirow[t]{2}{*}{$-2,294$} & \multirow[t]{2}{*}{153} & \multirow[t]{2}{*}{ 023 } \\
\hline & Özel & 43 & 42,53 & 6,419 & ,979 & & & \\
\hline \multirow{2}{*}{ Kişilik } & Devlet & 112 & 42,58 & 6,067 & ,573 & \multirow[t]{2}{*}{,- 582} & \multirow[t]{2}{*}{153} & \multirow[t]{2}{*}{,561 } \\
\hline & Özel & 43 & 43,21 & 5,910 & ,901 & & & \\
\hline \multirow{2}{*}{$\begin{array}{l}\text { Toplam } \\
\text { Ölçek }\end{array}$} & Devlet & 112 & 109,86 & 14,708 & 1,390 & \multirow[t]{2}{*}{$-1,226$} & \multirow[t]{2}{*}{153} & \multirow[t]{2}{*}{,222 } \\
\hline & Özel & 43 & 113,21 & 16,578 & 2,528 & & & \\
\hline
\end{tabular}

Tablo 18'de görüldüğü üzere, öğretmenlerin okul müdürlerinde algıladıkları okul müdürünün öğretmeni etkileme gücünün, okul türü değişkenine göre anlamlı bir farklılık gösterip göstermediğini belirlemek amacıyla yapılan bağımsız grup $t$ testi sonucunda uzmanlık gücü ile etkileme alt boyutunda anlamlı farklılık bulunurken ( $\mathrm{t}=-$ $2,294 ; \mathrm{p}<.05)$ toplam ölçek ve diğer alt boyutlarda grupların aritmetik ortalamaları arasında istatistiksel olarak anlamlı farklılık bulunmamıştır ( $\mathrm{t}=-, 081 ; \mathrm{p}>.05 ; \mathrm{t}=-$ ,582; $>$ >.05; $t=-1,226 ; p>.05)$. Özel okullarda çalışan öğretmenler uzmanlık alt boyutunda devlet okulunda çalışanlara göre daha olumlu değerlendirmelerde bulunurken yetki, kişilik ve toplam ölçekte ise anlamlı farklılık görülmemiştir.

Tablo 19. Okul müdürlerinin yönetim Becerileri Ölçeği Öğretmenleri Etkileme Güçleri Arasındaki İlişkiyi Belirlemek Üzere Yapılan Pearson Korelasyon Analizi Sonuçları

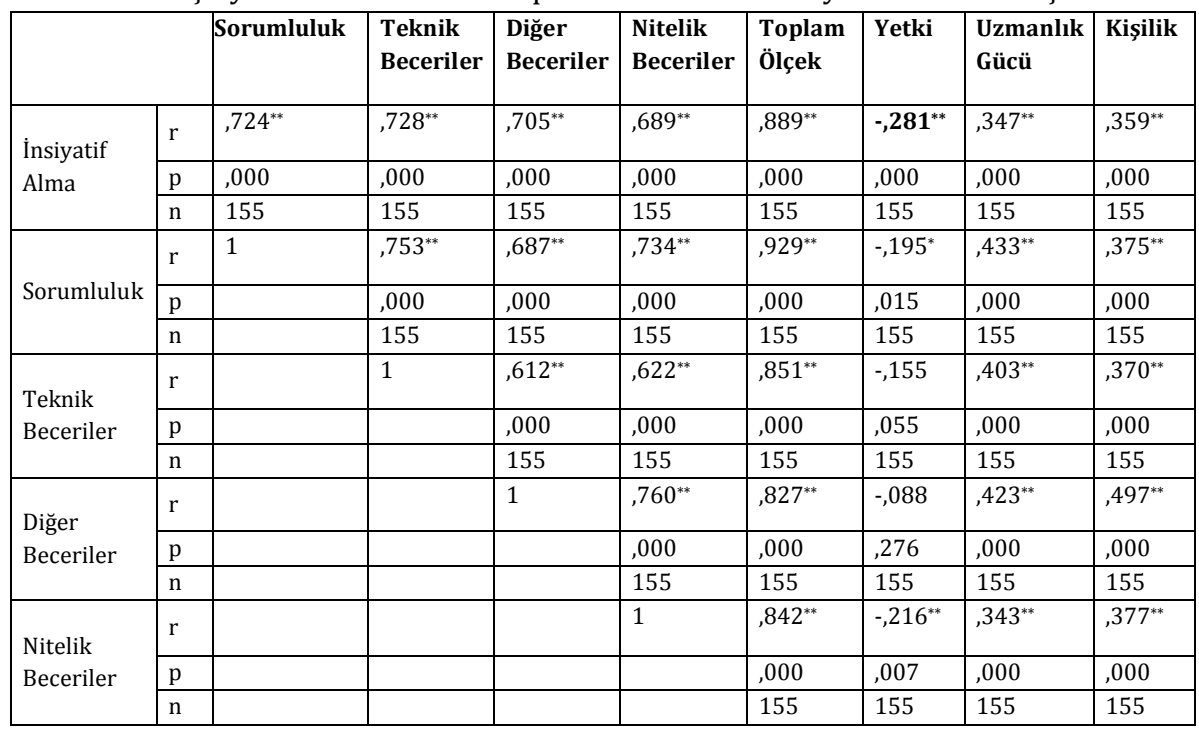




\begin{tabular}{|l|l|l|l|l|l|l|l|l|l|}
\hline \multicolumn{2}{|c|}{} & Sorumluluk & $\begin{array}{l}\text { Teknik } \\
\text { Beceriler }\end{array}$ & $\begin{array}{l}\text { Diğer } \\
\text { Beceriler }\end{array}$ & $\begin{array}{l}\text { Nitelik } \\
\text { Beceriler }\end{array}$ & $\begin{array}{l}\text { Toplam } \\
\text { Ölçek }\end{array}$ & Yetki & $\begin{array}{l}\text { Uzmanlık } \\
\text { Gücü }\end{array}$ & Kişilik \\
\hline \multirow{3}{*}{$\begin{array}{l}\text { Toplam } \\
\text { Ölçek }\end{array}$} & $\mathrm{r}$ & & & & & 1 &,$- 225^{* *}$ &, $447^{* *}$ &, $438^{* *}$ \\
\cline { 2 - 10 } & $\mathrm{p}$ & & & & & &, 005 &, 000 &, 000 \\
\cline { 2 - 10 }
\end{tabular}

Tablo 19'da görüldüğü üzere, öğretmen görüşlerine göre okul müdürlerinin yönetim becerileri ile öğretmenleri etkileme güçleri arasındaki ilişkileri belirlemek üzere Pearson momentum çarpımı korelasyon analizi yapılmıștır. Analiz sonucunda yönetim becerileri ölçeği toplam puanları ve alt boyut puanları ile etkileme ölçeğinin yetki gücü alt boyutu arasında negatif yönde ilişki olduğu görülmüştür. Yönetim becerileri ölçeği puanları ile etkileme ölçeğinin alt boyutları olan uzmanlık gücü ve kişilik boyutları ile pozitif yönde anlamlı ilişki bulunmuştur. Buna göre yetki yönetim becerileri azaldıkça yetki gücünün kullanımı artmaktadır. Bu durumun aksine yönetim becerileri arttıkça uzmanlık ve kişilik güçlerinin kullanımı da artmaktadır.

\section{Tartışma ve Sonuç}

Araştırmanın bulguları genel olarak öğretmenlerin okul müdürlerinde algıladıkları yönetim becerilerinin yüksek düzeyde olduğunu göstermektedir. Bu bulguya benzer şekilde Gezer (2015), Şekerci (2006) ve Mangaltepe (2012) ilköğretim okulu öğretmenlerinin okul müdürlerinin yönetim becerilerini gösterme düzeylerini katılıyorum olarak bulmuştur. Öztürk (2012) ise ilköğretim okul müdürlerinin yönetici becerileri genellikle düzeyinde bulmuştur.

Öğretmenlerin okul müdürlerinde algıladıkları yönetim becerileri cinsiyet değişkenine göre grupların aritmetik ortalamaları arasında toplam ölçekte ve diğer alt boyutlarda istatistiksel olarak anlamlı farklılık göstermemektedir. Bu bulguları destekler nitelikte Gezer (2015) ve Mangaltepe (2012) ilköğretim okulu öğretmenlerinin okul müdürlerinin yönetim becerilerini gösterme düzeylerine ilişkin algıları cinsiyet, değişkenlerine göre anlamlı fark bulmamıștır. Cinsiyet değișkeni bakımından, yöneticilerin karmaşık sorunların çözümü ve iletişim becerileri alt boyutlarında sergiledikleri yönetici becerilerine ilişkin öğretmen görüşlerinde anlamlı farklılıklar tespit edilmiştir. Kadın öğretmenler her iki alt boyutta da erkeklere oranla daha olumlu görüş taşıdıkları görülmüştür.

Öğretmenlerin okul müdürlerinde algıladıkları yönetim becerileri medeni durum, yaș, kıdem, öğrenim durumu değişkenlerine göre grupların aritmetik ortalamaları arasında toplam ölçek ve hiçbir alt boyutta anlamlı farklılık göstermemektedir. Bu bulguyu destekler nitelikte Gezer (2015) okul müdürlerinin yönetim becerilerinin öğretmen algılarına göre yaş, medeni durum, kıdem, okutulan sınıf ve mezuniyet değişkenine göre anlamlı bir fark tespit edilmemiştir. Mangaltepe (2012) de branş ve eğitim durumu değişkenlerine göre anlamlı fark tespit etmemiştir. Bunun yanında farklı olarak ise ilköğretim okulu öğretmenlerinin okul müdürlerinin yönetim becerilerini gösterme düzeylerine ilişkin algıları, kıdem değişkenine göre anlamlı fark göstermiştir. Yaş değişeni açısından öğretmenlerin okul yöneticilerinin 
yönetsel becerilerine ilişkin görüşlerinde anlamlı bir fark görülmemiştir. Mesleki kıdem değişkeni bakımından, öğretmenlerin okul yöneticilerinin yönetsel becerilerine ilişkin görüşlerinde anlamlı bir farklılık görülmemiştir.

Öğretmenlerin okul müdürlerinde algıladıkları yönetim becerileri okuldaki çalışma süresi değişkenine göre grupların aritmetik ortalamaları arasında teknik beceriler alt boyutunda anlamlı farklılık gösterirken toplam ölçek ve diğer alt boyutlarda anlamlı farklılık bulunmamıştır. Teknik beceriler alt boyutunda söz konusu farklılığın 1. Yıl çalışanlar ile 2 yıl çalışanlar arasında 1 yıl çalışanlar lehine anlamlı farklılık görülmüştür. 1 yıl çalışanlar yöneticileri daha olumlu değerlendirmektedirler. Diğer grup arasında farklılık yoktur.

Okul müdürlerinin yönetim becerileri okul türü değișkenine göre sorumluluk alma ve teknik beceriler alt boyutlarında anlamlı farklılık gösterirken toplam ölçek ile diğer alt boyutlarda anlamlı farklılık bulunmamıştır. Okul yöneticilerinin kullandıkları güç kaynaklarına ilişkin olarak Titrek ve Zafer (2009) okul yöneticilerinin en çok yasal ve zorlayıcı gücü, en düşük düzeyde ise ödül gücünü kullandıkları belirlenmiştir. Araştırma boyutların ortalama puanlarına göre resmi ve özel ilköğretim okulu işgörenlerinin görüşleri arasındaki anlamlı farklara dayanarak uzmanlık, karizmatik, ödüllendirme, yasal ve zorlayıcı güç boyutlarında değerlendirilen, yöneticilerin kullandıkları örgütsel güç kaynaklarının özel okullarda resmi okullara oranla daha olumlu olduğu belirlenmiştir. Eğitim durumuna göre örgütsel gücün karizmatik güç ve ödüllendirme gücü boyutlarında anlamlı farkın olduğu saptanmıştır. 21 yıl ve üstü kıdeme sahip olan isgörenlerin, diğerlerine göre örgütsel güç kaynaklarının tüm boyutlarında okul yöneticilerinin olumlu görüş sergiledikleri görülmüştür.

Öğretmenlerin algılarına göre okul müdürlerinin öğretmenleri etkileme ölçeğinde en yüksek etkileme tarzının kişilikle etkileme, daha sonra uzmanlıkla etkileme ve en az ise yetkiyle etkileme olduğu görülmüştür. Bu bulguyu destekler nitelikte Gezer (2015) okul müdürlerinin öğretmenleri etkilemelerinin öğretmen algısına göre orta düzeyde olduğu görülmüştür. Uygun (2006) ise okul müdürlerinin öğretmenleri etkileme ortalamasına bakıldığında; yetki ve kişilik ile çoğu zaman etkilediği, ancak; uzmanlık ile ara sıra etkilediği görülmekte iken, genel etkileme durumuna bakıldığında ise çoğu zaman etkilediği görülmüştür. Yetim (2010) tarafından yapılan çalışmada göreve yönelik iletişim alt boyutunda diğer alt boyutlara nazaran düşük puanlar tespit etmiştir. Bu durum, yöneticilerin iletişim becerilerinin göreve yönelik iletişim alt boyutunda öğretmen algılarına göre diğer boyutlardan daha az yeterli oldukları șeklinde yorumlanabilir.

Okul müdürünün öğretmeni etkileme gücü cinsiyet, yaş, okuldaki çalışma süresi değişkenlerine grupların aritmetik ortalamaları arasında istatistiksel olarak anlamlı farklılık göstermemektedir. Bu bulguyu destekler nitelikte Gezer (2015) okul müdürlerinin öğretmenleri etkilemelerinin öğretmen algısına göre cinsiyet, okutulan sınıf ve mezuniyet değişkenlerinde anlamlı ölçüde farklılaşmamaktadır. İlköğretim okulu öğretmenlerinin okul müdürlerinin öğretmenleri etkileme davranışlarını gösterme düzeylerine ilişkin algıları cinsiyet, branş, kıdem ve eğitim durumu değişkenlerine göre anlamlı fark göstermemektedir. Uygun (2006) ise okul müdürlerinin yetki, uzmanlık ve kişilik değişkenlerinde, öğretmenlerin kıdem ve 
öğretmenliğe temel eğitimlerine göre etkileme düzeylerinde, anlamlı bir farklılığın olmadığı, ancak; öğretmenlerin cinsiyetlerine göre uzmanlık ile etkilemede bayan öğretmenleri etkileme düzeyinde anlamlı bir farklılığın olduğu, öğretmenlerin branşlarına göre, her üç boyutta da etkileme düzeylerinde anlamlı bir farklılığın olduğu, yetki ile etkileme düzeyinde; sınıf öğretmenleri ile sosyal bilimler ve dil bilimleri branşlarında bulunan öğretmenler arasında, uzmanlık ile sınıf öğretmeni ile güzel sanatlar (resim, müzik, beden eğitimi vb.) branşlarında bulunan öğretmenler arasında, kişilik ile etkilemede ise; sınıf öğretmeni ile bütün branşlar arsında etkileme düzeyleri anlamlı bir farklılık göstermektedir. Bu bulgulardan farklı olarak Derya (2010) Etkileme taktiklerini kullanım eğilimleri ile demografik özelliklerin farklılaşıp farklılaşmadığına baktığımızda; bayanların mantıksal deliller ve açıklamalar ile ikna etme ve çalışanların görüş ve düşüncelerine başvurma davranışlarına erkeklerden daha çok yöneldikleri görülmüştür. Bekar yöneticilerin evli olanlara nazaran çalışanları sıkı denetleyerek onları korkutma ve baskıcı davranma yoluna başvurduklarını görülmüştür.

Okul müdürünün öğretmeni etkileme gücü medeni durum değişkenine toplam ölçek ve kişilikle etkileme alt boyutunda anlamlı farklılık gösterirken yetki ve uzmanlık gücüyle etkileme alt boyutlarında grupların aritmetik ortalamaları arasında istatistiksel olarak anlamlı farklılık bulunmamıştır. Bu bulgudan farklı olarak Gezer (2015) okul müdürlerinin öğretmenleri etkilemelerinin medeni durum değişkeninde anlamlı bir farklılık bulmuştur.

Okul müdürünün öğretmeni etkileme gücü kıdem değişkenine göre yetki yoluyla etkileme alt boyutunda anlamlı farklılık gösterirken toplam ölçek ile diğer alt boyutlarda grupların aritmetik ortalamaları arasında istatistiksel olarak anlamlı farklılık bulunmamıştır. Bu bulguyu destekler nitelikte Gezer (2015) kıdem değişkenine göre grupların aritmetik ortalamaları arasındaki farklılık yetki alt boyutunda anlamlı bulunurken diğer alt boyutlarda ve toplam ölçekte anlamlı bulunmamıştır. Deniz ve Çolak'ın (2008) bulguları da bu bulgularla yakınlık göstermektedir. Derya (2010) ise genç yöneticilerin yaşça büyük olanlara göre, çalışanlarının yeteneklerini övme, baskıcı davranma, değiş-tokuş politikasını gütme gibi yöntemlerden yararlandıkları görülmüştür.

Okul müdürünün öğretmeni etkileme gücü ölçeği puanlarının öğrenim durumu değişkenine göre toplam ölçek ve yetki yoluyla etkileme alt boyutunda anlamlı farklılık bulunurken diğer alt boyutlarda grupların aritmetik ortalamaları arasında istatistiksel olarak anlamlı farklılık bulunmamıştır. Derya da (2010) eğitim düzeyi düşük yöneticilerin astlarına daha baskıcı davrandıklarını, işbirliğine önem verdikleri ve onları heyecanlandırarak motive etme yollarını seçtiklerini bulmuştur.

Okul müdürünün öğretmeni etkileme gücü ölçeği puanlarının okul türü değişkenine göre uzmanlık gücü ile etkileme alt boyutunda anlamlı farklılık bulunurken toplam ölçek ve diğer alt boyutlarda grupların aritmetik ortalamaları arasında istatistiksel olarak anlamlı farklılık bulunmamıștır.

Yönetim becerileri ölçeği ile okul müdürlerinin öğretmenleri etkileme ölçeğinin uzmanlık gücü ve kişilik boyutları arasında pozitif yönde anlamlı ilişki bulunmuştur. Yönetim becerileri arttıkça okul müdürlerinin öğretmenleri etkileme puanları da artmaktadır. BU bulguları destekler nitelikte Gezer (2015) yönetim becerileri arttıkça 
okul müdürlerinin öğretmenleri etkileme puanları da arttığını tespit etmiştir. Bu durum pozitif korelasyonu göstermektedir. Şekerci (2006) de benzer șekilde ilköğretim okulu yöneticilerinin yönetim becerileri ile grup etkililiği arasında öğretmen algılarına göre anlamlı bir ilişki vardır. Mangaltepe (2012) ilköğretim okulu öğretmenlerinin, okul müdürlerinin yönetim becerileri ile öğretmenleri etkileme becerileri ilişkin algıları arasında "yüksek" düzeyde pozitif yönlü ilişki olduğu saptanmıştır. Taşçı ve Eroğlu (2007) ise gerek kurum içi halkla ilişkiler faaliyetlerinde gerek diğer örgütsel iletişim faaliyetlerinde olsun yöneticiler çalışanlarını ikna etmek ya da etkilemek için birtakım çabalar içine girmektedirler. Bu ikna ve etkileme çabaları içinde yöneticilerin kişilikleri önemli bir rol oynamaktadır. Sonuçta bazı kișilik özellikleri ile kullanılan ikna taktikleri arasında ilişkiler bulunmuștur.

Bu sonuçlar ilgili literatürle uyumlu olarak öğretmenlerin yetki gücünü olumsuz bir güç olarak algıladıklarını göstermektedir. Öğretmenler, yöneticilik becerileri zayıf olan okul yöneticilerinin daha fazla yetki gücü kullandıklarını düşünmektedir. Yöneticilik becerilerinin artması uzmanlık ve kişiliğe dayalı olan ve öğretmenler üzerinde daha etkili olan güçlerin kullanımını da artırmaktadır. Bu bulgular yönetim becerilerinin geliştirilmesine yönelik çabaların önemini bir kez daha ortaya koymaktadır.

\section{KAYNAKÇA}

AÇIKALIN, Aytaç ve Mehmet ŞIŞMAN, Bir insan olarak okul müdürü, Ankara, Pegem A., 2007.

AKÇAY, Ahmet, 'Okul Müdürleri Öğretmenlerini Etkileyebiliyor Mu?' Milli Eğitim Dergisi, 2003, 157, 75-88.

AYDIN, Mustafa, Eğitim yönetimi, Ankara, Hatiboğlu Yayınları, 2005.

BALCI, Ali ve AYDIN, İnayet Pehlivan, Anadolu Öğretmen Liseleri İçin Eğitim

Yönetimi, Ankara, OSTİM Mesleki Eğitim Merkezi, 2001.

BALCI, Ali, Eğitim yönetimi terimleri sözlüğü, Ankara, Tek Ağaç Yayıncılık, 2005.

BAȘARAN, İbrahim Ethem, Türk Eğitim Sistemi ve Okul Yönetimi, Ankara, Ekinoks Basım Yayım ve Dağıtım, 2006.

BURSALIOĞLU, Ziya, Okul yönetiminde yeni yapı ve davranış, Ankara, Pegem, 2012.

CEYHAN, Esra, Erken Çocukluk Döneminde Gelişim-1, Eskişehir, Anadolu Üniversitesi, 2011.

ÇELİK, Vehbi, Eğitimsel Liderlik, Ankara, Pegem A Yayıncılık, 2003.

DERYA, Seher, Liderlik Tarzları ve Liderlerin Astlarını Etkileme Taktikleri Arasındaki İlişki: Antalya İli 5 Yıldızlı Otel Yöneticileri Üzerinde Bir Araştırma, Yayınlanmamış Yüksek Lisans Tezi, T.C. Süleyman Demirel Üniversitesi Sosyal Bilimler Enstitüsü İșletme Anabilim Dalı, 2010. 
EREL YETIM, Ayşe Ece, Genel Liselerde Örgütsel İletişim İle Öğretmenlerin Örgütsel Özdeşlemeleri Arasındaki İlişki, Yayınlanmamış Lisansüstü Tezi, Gazi Üniversitesi Eğitim Bilimleri Enstitüsü, Ankara. 2010.

GEZER, Eren, Eğitim Yöneticilerinin Yönetim ve Öğretmenleri Etkileme Becerilerinin Öğretmenler Tarafından Değerlendirilmesi, Yayınlanmamış Yüksek Lisans Tezi, İstanbul Sabahattin Zaim Üniversitesi Sosyal Bilimler Enstitüsü Eğitim Bilimleri Anabilim Dalı Eğitim Yönetimi ve Denetimi, 2015.

GÜLTEKIN, Mehmet, 'İlköğretime Hazırlık ve İlköğretim Programları', Okul Öncesi Eğitim ve İlköğretim (Ed. Yaşar, Ş.), Eskişehir, Anadolu Üniversitesi, 2008.

GÜRSEL, Musa, Türk eğitim sistemi ve okul yönetimi, Konya, Eğitim

Yayınevi, 2007

KARASAR, Niyazi, Bilimsel Araştırma Yöntemleri, Ankara, Nobel Yayınları, 2006.

KOÇEL, Tamer, İşletme Yöneticiliği, İstanbul, Beta Basım Yayım Dağıtım, 2011.

MANGALTEPE, Emrah, İlköğretim okul müdürlerinin yönetim Beceriler ile öğretmenler etkileme becerilerine ilişkin öğretmen görüşleri, Yayınlanmamış Yüksek lisans tezi, Abant İzzet Baysal Üniversitesi, Eğitim Bilimler Enstitüsü, Eğitim Yönetim ve Denetim Anabilim Dall, 2012.

ÖZTÜRK, Necati, İlköğretim Okul Müdürlerinin Öğretmenler Tarafından Algılanan Yönetici Becerileri İle Öğretmenlerin İş Doyumu Arasındaki İlişki, Yayınlanmış Yüksek Lisans Tezi Gaziantep Üniversitesi Sosyal Bilimler Enstitüsü Eğitim Bilimleri Ana Bilim Dalı, 2012.

ŞEKERCİ, Murat, İlköğretim Okulu Yöneticilerinin Yönetim Becerileri İle Grup Etkililiği Arasındaki İlişki, Yayınlanmamış Yüksek Lisans Tezi, Çanakkale Onsekiz Mart Üniversitesi, 2006.

ŞişMAN, Mehmet, Okul Yönetimi ve Öğretim Liderliği, Eğitime Bakış, 2017, 1, s.

TAŞÇI, Deniz ve EROĞLU, Erhan, "Yöneticilerin Kişilik Özellikleri ile Kullandıkları İkna ve Etkileme Taktiklerinin Kullanım Sıklığı Arasındaki İlişkinin Değerlendirilmesi." Selçuk Üniversitesi Sosyal Bilimler Enstitüsü Dergisi, 2007, 1(17), ss. 533-546.

TAYMAZ, Haydar, İlköğretim ve orta öğretim okul müdürleri için okul yönetimi: okul yöneticisinin iş alanları, alanlara giren işler, işlerin işlemleri, işlem basamakları, Ankara, Pegem A Yayıncılık, 2003.

TİTREK, Osman ve ZAFER, Demet, İlköğretim Okulu Yöneticilerinin Kullandıkları Örgütsel Güç Kaynaklarına İlişkin Öğretmen Görüşleri, Kuram ve Uygulamada Eğitim Yönetimi, 2009, 15 (60), ss. 657-674.

UYGUN, Himmet, İlköğretim Okulu Öğretmenlerinin Algılarına Göre Okul Müdürleri ile İlköğretim Müfettişlerinin öğretmenleri Etkileme Düzeyi, Yayınlanmamış Yüksek Lisans Tezi, Dokuz Eylül Üniversitesi, Eğitim Bilimleri Enstitüsü, 2006.

YÜKSEL, Ahmet Haluk, İkna Edici İletişim (Ed. Oyman, M.), Eskişehir, Anadolu Üniversitesi, 2012. 


\section{Summary}

As in all levels of education, the efficiency of education in preschool education depends on the realization of school objectives. The realization of the objectives of the school administration depends to a large extent on the fact that the school administrator has the management and leadership competencies and can apply them and influence the employees. Management skills include managing management processes in institutions in the most general sense. The Pre-School Principal's role to motivate pre-school teachers and taking measures which will improve educational and administrative procedures will have a positive impact on productivity and performance. For that reason, in this study, the relationship between the management skills and influence tactics of the principals are examined through pre-school teachers' point of view.

Because the research is trying to describe the current situation as it is, the correlational model has been adopted. The sample of the study is formed by the teachers who work within the boundaries of Tuzla and Pendik's public and private preschool educational institutions between the 2015-2016 academic years in Istanbul. This sample of 155 teachers are simply selected by convenient sampling method.

To collect research data "The Influence Scale of School Principals On Their Teachers", "Management Skills Scale" and "A Personal Information Form" were used. In the first place responses given by teachers analysed using frequencies arithmetic means and standard deviations. In order to compare two groups, the " $t$ " test have been used, in situations for comparing more than two groups of variables, one-way analysis of variance (ANOVA) was used. In situations where the difference was found meaningful, the Scheffe (multiple comparisons) test was applied. The Pearson product-moment correlation analysis was conducted to detect the relation between the management skills and the ability to have an influence on teachers.

According to the teachers' opinions, the management skills of school principals do not show a significant difference according to the variables of gender, marital status, age, seniority and education level in total scale and no sub-dimension. According to the teachers' views, there was a significant difference in the sub-dimension of technical skills of the school principals according to the working time of the school, while there was no significant difference in total scale and other sub-dimensions. In the technical skills subdimension, it was observed that this difference was in favor of one-year employees and oneyear employees among 2-year employees. 1 year employees evaluate managers more positively. There is no difference between the other group. According to the teachers' opinions, the management skills of school principals differ significantly in the subdimensions of taking responsibility according to the type of school and technical skills. On the other hand, no significant difference was found between the total scale and other subdimensions.

According to the opinions of teachers, the way school principals affect teacher did not show a statistically significant difference according to gender, age and working time variables. According to the teachers' views, the effect of school principals on the effect of teachers on teachers was not significantly different in the sub-dimension of authority and competency. The effect of school principals on the effect of authority according to the 
seniority variable shows a significant difference. On the other hand, there were no statistically significant differences between the groups in the total scale and other subdimensions. The effect of school principals on how to influence teachers differed significantly according to the educational status variable with total scale and authority sub-dimension, whereas there were no significant differences between the groups in other sub-dimensions. The way school principals affect teachers differ significantly according to the type of school variable with the power of expertise. However, there were no significant differences in the total scale and other sub-dimensions.

Pearson momentum product correlation analysis was conducted to determine the relationships between school principals' management skills and their ability to influence teachers. As a result of the analysis, it was observed that there was a negative relationship between the management skills scale total scores and sub-dimension scores, and the authority power sub-dimension of the influence scale. Significant relationship was found between the management skills scale scores and the sub-dimensions of the influence scale, which was positive with the expertise and personality dimensions. Accordingly, the use of power of authority increases as authority management skills decrease. Contrary to this situation, the use of expertise and personal powers increases as management skills increase.

These results show that teachers perceive the power of authority as a negative power in accordance with the relevant literature. Teachers think that school administrators who have poor management skills use more power. Increasing managerial skills also increases the use of powers that are based on expertise and personality and which are more effective on teachers. These findings once again demonstrate the importance of efforts to improve management skills. 